This PDF is a selection from a published volume from the National Bureau of Economic Research

Volume Title: The Distributional Aspects of Social Security and Social Security Reform

Volume Author/Editor: Martin Feldstein and Jeffrey B. Liebman, editors

Volume Publisher: University of Chicago Press

Volume ISBN: 0-226-24106-8

Volume URL: http://www.nber.org/books/feld02-1

Conference Date: October 21-23, 1999

Publication Date: January 2002

Title: Distributional Effects in a General Equilibrium Analysis of Social Security

Author: Laurence J. Kotlikoff, Kent Smetters, Jan Walliser

URL: http://www.nber.org/chapters/c9754 


\title{
Distributional Effects in a General Equilibrium Analysis of Social Security
}

\author{
Laurence J. Kotlikoff, Kent Smetters, and Jan Walliser
}

\subsection{Introduction}

This paper reviews and extends our recent general equilibrium analyses of the distributional effects of Social Security. The model is based on the Auerbach and Kotlikoff (1987) model, which computes the perfect foresight transition path of a life-cycle economy consisting of multiple overlapping generations. However, unlike the original Auerbach-Kotlikoff model, the new version of the model includes intragenerational heterogeneity and a much more detailed specification of U.S. fiscal institutions. ${ }^{1}$ The latest version of the model, which is still in a very preliminary state, incorporates a more realistic pattern of births and length of life.

We reach six conclusions. First, Social Security's privatization can substantially raise long-run living standards. However, achieving these gains will take a considerable amount of time and will entail some welfare losses to transition generations. Second, Social Security's privatization helps the long-run poor even absent any explicit redistribution mechanism. This reflects both the opportunity cost of the current pay-as-you-go system as well as the impact of privatization on capital deepening. Third, privatizations that feature voluntary rather than compulsory exit from the old system

Laurence J. Kotlikoff is professor of economics at Boston University and a research associate of the National Bureau of Economic Research. Kent Smetters is assistant professor of insurance and risk management at the Wharton School, University of Pennsylvania, and a faculty research fellow of the National Bureau of Economic Research. Jan Walliser is in the Fiscal Affairs Department of the International Monetary Fund.

The authors thank the National Bureau of Economic Research, the Smith Richardson Foundation, the National Institute of Aging, and Boston University for research support.

1. Prior applications of the AKSW Model include Kotlikoff (1996), Kotlikoff, Smetters, and Walliser (1997, 1998a, b, and 1999a, b), and Altig et al. (1997). 
have particularly low transition costs and particularly favorable macroeconomic and distributional consequences despite the adverse selection they entail. Fourth, privatizations, like those advocated by the World Bank (1994), that provide a flat (minimum) benefit, can actually make the longrun poor worse off relative to privatizations without a flat benefit because they pay-as-you-go finance the flat benefit with a significant payroll tax. Fifth, combining privatization with a progressive match to contributions benefits the lifetime poor relative to privatization without a match. Sixth, when America's aging is considered, the long-run gains to Social Security's privatization are greater because the status-quo alternative entails a substantial long-run increase in the rate of payroll taxation.

The paper proceeds in section 8.2 with a review of some of the recent simulation literature on Social Security. Section 8.3 describes our base model, which does not include our newest enhancements to the demographic structure. Section 8.4 uses the model to explore privatization. The results presented here draw on Kotlikoff, Smetters, and Walliser (1997, $1998 \mathrm{a}, \mathrm{b}$, and $1999 \mathrm{a}, \mathrm{b})$. Section 8.5 presents some very preliminary results using the demographic variant of the model. Section 8.6 concludes.

\subsection{Literature Review}

Feldstein's (1974) seminal article on Social Security's impact on national saving has, over the years, stimulated a plethora of related studies. The majority of these have been theoretical and empirical, but a growing number involve simulating Social Security's dynamic general equilibrium effects within macroeconomic models that have microeconomic foundations. Early contributions here include Kotlikoff (1979), Auerbach and Kotlikoff (1983), and Seidman (1986). These papers confirmed Feldstein's theoretical prediction and empirical finding that unfunded Social Security systems significantly reduce nations' long-run capital intensivities and living standards. Kotlikoff and Auerbach-Kotlikoff examined how introducing "pay-as-you-go" (PAYGO) Social Security would worsen an economy's economic position, notwithstanding induced changes in retirement behavior. Seidman's in contrast, appears to be the first to study the economic gains from eliminating unfunded Social Security.

More recent contributions include Auerbach and Kotlikoff (1987), Auerbach et al. (1989), Hubbard and Judd (1987), Hansson and Stuart (1989), Arrau and Schmidt-Hebbel (1993), Kotlikoff (1996), Hubbard, Skinner, and Zeldes (1994a, b, and 1995), Kotlikoff, Smetters, and Walliser (1997, 1998a, b, and 1999a, b), Huang, İmrohoroğlu, and Sargent (1997), and İmrohoroğlu, İmrohoroğlu, and Joines (1995, 1999), Knudsen et al. (1999), Fougere and Merette (1998, 1999), Schneider (1997), Raffelhuschen (1993), Cooley and Soares (1999a, b), Huggett and Ventura (1999), De Nardi, İmrohoroğlu, and Sargent (1999), Galasso (1999), and others. These studies have included a range of additional important factors, in- 
cluding demographics, land, earnings uncertainty, liquidity constraints, and majority voting on the system's continued existence. They have also examined the different ways a transition to a privatized Social Security system could be financed.

\subsection{Description of Our Model}

This section describes our base model as well as its calibration and solution methods. It draws heavily on similar descriptions in Altig et al. (2001), Kotlikoff, Smetters, and Walliser (1999a, b), and the review presented in Kotlikoff (2000). Section 8.5 describes how the model presented in this section is currently being modified to more accurately capture demographics. We report some very preliminary simulation results in that section.

\subsubsection{Demographic Structure}

The model contains a fixed number of overlapping cohorts. Each period in the model corresponds to a year. Adults live for fifty-five years (from age twenty-one through seventy-five). Like that of Fullerton and Rogers (1993), our model incorporates intragenerational heterogeneity in the form of twelve lifetime-earnings groups. Each group has its own initial skill level and its own longitudinal age-skill profile. The twelve groups also have distinct bequest preferences. Our model has both advantages and disadvantages relative to Fullerton and Rogers's (1993) model. Some of the advantages are the inclusion of a Social Security system, a detailed description of non-Social Security taxes, the existence of government debt and endogenous bequests, and the ability to compute the economy's perfect-foresight transition path. The principal disadvantage is the lack of a highly detailed production sector that includes multiple sectors and intermediate production. However, the omission of this production sector detail may matter little for our purposes, because the Social Security policies we examine do not differentially affect particular industries or types of capital goods.

\subsubsection{Preferences and Budget Constraints ${ }^{2}$}

Each $j$-type agent who begins her economic life at date $t$ chooses perfectforesight consumption paths $(c)$, leisure paths $(l)$, and intergenerational transfers $(b)$ to maximize a time-separable utility function of the form.

$$
U_{t}^{j}=\frac{1}{1-\frac{1}{\gamma}}\left\{\sum_{s=21}^{75} \beta^{s-21}\left(c_{s, t+s-21}^{j^{1-1 / \rho}}+\alpha l_{s, t+s-21}^{j^{1-1 / \rho}}\right)\left[\left(1-\frac{1}{\gamma}\right) /\left(1-\frac{1}{\rho}\right)\right]+\beta^{54} \mu^{j} b_{75, t+54}^{j^{1-1 / \gamma}}\right\}
$$

In equation (1), $\alpha$ is the utility weight on leisure, $\gamma$ is the intertemporal elasticity of substitution in the leisure-consumption composite, and $\rho$ is 
the intratemporal elasticity of substitution between consumption and leisure. The parameter $\mu^{j}$ is a $j$-type specific utility weight placed on bequests left to each child when the agent dies. The term $\beta=1 /(1+\delta)$, where $\delta$ is the rate of time preference, is assumed to be the same for all agents.

Letting $a_{s, t}^{j}$ be capital holdings for type $j$ agents, of age $s$, at time $t$, maximization of equation (1) is subject to a sequence of budget constraints given by

$$
\begin{gathered}
a_{s+1, t+1}^{j}=\left(1+r_{t}\right)\left(a_{s, t}^{j}+g_{s, t}^{j}\right)+w_{s, t}^{j}\left(E_{s, t}^{j}-l_{s, t}^{j}\right)-c_{s, t}^{j} \\
-\sum_{k \in \tilde{\mathrm{T}}} T^{k}\left(B_{s, t}^{j, k}\right)-N b_{s, i}^{j} \\
l_{s, t}^{j} \leq E_{s, t}^{j}
\end{gathered}
$$

where $r_{t}$ is the pretax return to savings, $g_{s, t}^{j}$ are gifts received from parents, $E_{s, t}^{j}$ is the time endowment, $b_{s, t}^{j}$ denotes bequests made to each of the $N=$ $(1+n)^{20}$ children, and the functions $T^{k}(\cdot)$ with tax base arguments $B_{s, t}^{j, k}$ determine net tax payments from income sources $k \in \tilde{T}=\{C, K, W, Y, P\}$. $T^{C}(\cdot), T^{K}(\cdot), T^{W}(\cdot), T^{Y}(\cdot)$, and $T^{P}(\cdot)$ are consumption taxes, capital income taxes, wage taxes, income taxes, and Social Security payroll taxes, respectively. Social Security benefits are represented in equation (2) as negative taxes with the base switching at the point of retirement from the contemporaneous payroll base to average indexed yearly earnings in the preretirement years. All taxes are collected at the household level, and the tax system includes both a personal income tax and a business profits tax. The bases for the wage and payroll taxes are smaller than total labor income due to the base reductions discussed below.

An individual's earning ability is an exogenous function of her age, her type, and the level of labor-augmenting technical progress, which grows at a constant rate $\lambda$. We concentrate all skill differences by age and type in an efficiency parameter $\varepsilon_{s}^{j}$. Thus, the wage rate for an agent of type $j$ and age $s$ is $w_{s, t}^{j}=\varepsilon_{s}^{j} w_{t}$, where $w_{t}$ is the growth-adjusted real wage at time $t . \varepsilon_{s}^{j}$ increases with age to reflect not only the accumulation of human capital, but also technical progress. To permit balanced growth for our specifications of preferences given the restriction on leisure shown in equation (2), we assume that technical progress also causes the time endowment of each successive generation to grow at rate $\lambda .{ }^{3}$ More precisely, if $E_{s, t}^{j}$ is the endowment of type $j$ at age $s$ and time $t$, then $E_{s, t}^{j}=(1+\lambda) E_{s, t-1}^{j}$, for all $s, t$, and $j$. Notice that the endowment $E_{s, t}^{j}$ depends only on an agent's year of birth. Because $E$ grows at rate $\lambda$ from one cohort to the next, there will be no underlying trend in $w_{t}$. The growth-adjusted earnings ability profiles take the form

3. See Auerbach et al. (1989) for a more complete discussion of this strategy for dealing with balanced growth. 


$$
\varepsilon_{s}^{j}=e^{a_{0}^{j}+a_{1}^{j} s^{2}+a_{3}^{j} s^{3}} .
$$

Values of the $a$ coefficients for $j$-type groups 1 through 12 -in ascending order of lifetime income - are based on regressions fitted to the University of Michigan's Panel Study of Income Dynamics and are taken from Altig et al. (2001). Groups 1 and 12 comprise the bottom and top 2 percent of lifetime wage income earners, and groups 2 and 11 the remaining 8 percent of the top and bottom deciles. All other groups constitute 10 percent of the population. For example, group 3 is the second decile of lifetime-wage income, group four the third decile, and so on up to group 10. The estimated longitudinal age-earnings-ability profiles are scaled to include the effects of technical progress. Given our benchmark parameterization, peak hourly wages valued in 1996 dollars are $\$ 4.00, \$ 14.70$, and $\$ 79.50$ for individuals in classes 1,6 , and 12, respectively. More generally, steady-state annual labor incomes derived from the model's assumptions and the endogenous labor supply choices range from $\$ 9,000$ to $\$ 130,000$. As discussed below, these calculations do not yet include labor compensation in the form of fringe benefits.

Bequests are received by children, with interest, at the beginning of the period after they are made by their parents. We restrict all parental transfers to bequests, so that $b_{s, t}^{j}=0$, for $s \neq 75$, and $g_{s, t}^{j}=0$, for $s \neq 56$. In the steady state, therefore, $g^{j}=b^{j}$, for all $j$ (where we have dropped the age subscripts for convenience). The parameters $\mu^{j}$ are derived endogenously for the initial steady state such that the ratio of the bequest to economywide mean income corresponds to the ratio originally estimated by Menchik and David (1982) and updated by Fullerton and Rogers (1993). Bequests range from $\$ 4,800$ to $\$ 450,000$ for the lowest and highest lifetime earnings classes, respectively.

The benchmark values for $\delta, \gamma, \rho$, and $n$ are those in Auerbach and Kotlikoff (1987). The parameter $\alpha$ is chosen so that agents devote, on average, about 40 percent of their available time endowment (of sixteen hours per day) to labor during their prime working years (real-life ages of roughly twenty-one to fifty-five).

\subsubsection{The Non-Social Security Government Budget Constraint}

At time $t$, the government collects tax revenues and issues debt $\left(D_{t+1}\right)$, which it uses to finance government purchases of goods and services $\left(G_{t}\right)$ and interest payments on the existing stock of debt $\left(D_{t}\right)$. Letting $\varphi^{j}$ be the fraction of $j$-type agents in each generation, the non-Social Security part of the government's budget constraint evolves according to

$$
D_{t+1}+(1+n)^{t} \sum_{j=1}^{12} \phi^{j} \sum_{s=21}^{75}(1+n)^{-(s-21)} \sum_{k \in\{\hat{T}-P\}} T^{k}\left(B_{s, t}^{j, k}\right)=G_{t}+\left(1+r_{t}\right) D_{t} .
$$

The exclusion of Social Security taxes in equation (4) reflects the fact that Social Security currently uses self-financing earmarked taxes. 
Government expenditures are assumed to be unproductive and generate no utility to households. ${ }^{4}$ The values of $G_{t}$ and $D_{t}$ are held fixed per effective worker throughout the transition path. Any reduction in government outlays resulting from a change in the government's real interest payments is passed on to households in the form of a lower tax rate. The level of government debt, $D_{t}$, was chosen such that the associated real interest payments equal about 3.5 percent of national income in the initial steady state. The statutory tax schedules (described below) generate a level of revenue above debt service such that the benchmark steady-state ratio of government purchases, $G_{t}$, to national income equals 0.239 . These values correspond very closely to the corresponding 1996 values for the combined local, state, and federal government in the United States.

\subsubsection{Non-Social Security Taxes}

The benchmark tax system in our initial steady state is designed to approximate the salient aspects of the 1996 U.S. (federal, state, and local) tax and transfer system. It features a hybrid tax system (incorporating wageincome, capital-income, and consumption tax elements) and payroll taxation for the Social Security and Medicare programs. To adjust for tax evasion, we reduce income taxes by 2.6 percentage points. This adjustment is consistent with the degree of tax evasion reported in Slemrod and Bakija (1996). In the various alternative tax structure experiments, we assume that evasion reduces the postreform tax base (income net of deductions and exemptions) by the same percentage as before the reform. Thus, the level of tax evasion falls when the tax base shrinks. We approximate the hybrid current U.S. tax system by specifying a progressive wage-income tax, a flat capital-income tax, a flat state income tax, and a flat consumption tax.

\section{Wage Income Taxation}

The wage-income tax structure has four elements: (a) a progressive marginal rate structure derived from a quadratic approximation to the 1996 federal statutory tax rates for individuals; (b) a standard deduction of $\$ 4,000$ and exemptions of $\$ 5,660$ (which assumes 1.2 children per agent, consistent with the model's population growth assumption); (c) itemized deductions - applied only when they exceed the amount of the standard deduction - that are a positive linear function of income estimated from data reported in the Statistics of Income ${ }^{5}$ and (d) earnings-ability profiles

4. Since $G$ remains fixed in all of our experiments, incorporating $G$ into the utility function is unimportant.

5. The data used in this estimation were taken from all taxable returns in tax year 1993. The function was obtained by regressing deductions exclusive of mortgage interest expense on the midpoints of reported income ranges. (The deduction of interest expense on home mortgages was included in our calculation of the capital-income tax rate, as we will subsequently describe.) The regression yielded a coefficient of 0.0755 with an $R^{2}$ equal to 0.99 . 
that are scaled to incorporate pension and nonpension components of labor compensation. ${ }^{6}$

The model's initial economy-wide average marginal tax rate on wage income is about 21 percent, roughly the figure obtained from NBER's TAXSIM model as reported in Auerbach (1996). The average wageincome tax rate equals 12.1 percent. For all individuals in the highest lifetime income class (group 12), the average effective marginal tax rate on labor income is 28.6 percent. The highest realized effective marginal tax rate is 34 percent. For lifetime income class six-whose members have peak labor earnings of about $\$ 35,000$ - the average tax rate and average marginal tax rate are 10.6 and 20.0 percent, respectively. For the poorest class (group one), the corresponding rates are zero and 5.5 percent. $^{7}$

\section{Capital Income Taxation}

Following Auerbach (1996), we assume that income from residential and nonresidential capital are taxed at flat rates of 6 percent and 26 percent, respectively. Given the roughly equal amounts of these two forms of capital, the effective federal marginal tax rate on total capital income is 16 percent. However, this rate applies only to new capital. Existing capital faces a higher tax rate, which, given depreciation schedules, is estimated to be 20 percent. We model this gap by assuming that all capital income faces a 20 percent tax, but that 20 percent of new capital may be expensed, thereby generating a 16 percent effective rate on new capital.

\section{State Income Taxation}

In addition to the federal taxation, both capital and wage income are subject to a proportional state income tax of 3.7 percent. This value corresponds to the amount of revenue generated by state income taxes in 1996 divided by national income.

\section{Consumption Taxation}

Consumption taxes in the initial steady state reflect two elements of the existing tax structure. First we impose an 8.8 percent tax on consumption expenditures consistent with values reported in the National Income and Product Accounts on indirect business and excise revenues. However, because contributions to both defined benefit and defined contribution pension plans receive consumption tax treatment, we levy an additional 2.5

6. Benefits as a function of adjusted gross income were kindly provided by Jane Gravelle of the Congressional Research Service and Judy Xanthopoulos of the Joint Committee on Taxation, respectively. On the basis of this information, we regressed total benefits on AGI. The regression yielded a coefficient of 0.11295 with an $R^{2}$ equal to 0.99 . In defining the wagetax base, we therefore exempt roughly 11 percent of labor compensation from the base calculations.

7. The average marginal rate for people with the lowest income exceeds zero due to positive shadow tax rates in peak earnings years. 
percent tax on household consumption goods expenditures to account for the indirect taxation of labor compensation in the form of pension benefits (Auerbach 1996). This 2.5 percent tax replaces the wage tax that otherwise would apply to labor compensation in the form of fringe benefits.

\subsubsection{Social Security, Medicare, and Disability}

The model has a social insurance system that incorporates Social Security Old Age and Survivors Insurance (OASI), Social Security Disability Insurance (DI), and public health insurance taking the form of Medicare (HI). OASI benefits are calculated according to the progressive statutory bend-point formula. U.S. Social Security benefits are based on a measure of average indexed monthly earnings (AIME) over a thirty-five-year work history. The AIME is converted into a primary insurance amount (PIA) in accordance with a progressive formula. In particular, the 1996 benefit formula has two bend points. The PIA is calculated as 90 percent of the first \$437 of AIME, 32 percent of the next \$2,198 of AIME, and 15 percent of AIME above $\$ 2,198$. We approximate the benefit formula with a sixthorder polynomial, which is applied to the dollar-scaled AIME generated by the model. This polynomial approximation is very accurate with $R^{2}=$ 0.99 . We achieve replacement values between 25 and 75 percent for the lifetime richest and lifetime poorest, respectively. Since approximately 50 percent of Social Security benefits are paid to survivors and spouses, we multiply benefits by a factor of two.

In ignoring spousal benefits and the fact that the rich live longer than the poor, we may be overstating the program's degree of progressivity. The papers by Liebman and by Coronado, Fullerton, and Glass (chapters 1 and 5 in this volume) investigate how these factors influence progressivity.

An earmarked tax applied to wage income up to a limit of $\$ 62,700$ the earnings ceiling in 1996-is used to pay for OASI benefits. Define $\omega_{s, t}^{j}$ $\equiv w_{s, t}^{j}\left(E_{s, t}^{j}-l_{s, t}^{j}\right)$ as the wage income earned by the $j$-type agent who is age $s$ in year $t$. Also define $\bar{\omega}_{65, t}^{j}$ as the average indexed annual earnings for the $j$-type agent aged sixty-five at time $t$. Labor income earned before turning age sixty-five is adjusted upward by the growth rate of the economy in calculating $\bar{\omega}_{65, t}^{j}$. Payroll taxes at time $t$ - with retirement benefits modeled as negative taxes-equal

$$
T^{P}\left(B_{s, t}^{j, k}\right)=\left\{\begin{array}{l}
\tau \cdot \omega_{s, t}^{J} ; s \leq 64, \omega_{s, t}^{J} \leq \$ 62,700 \\
\tau \cdot \$ 62,000 ; s \leq 64, \omega_{s, t}^{j}>\$ 62,700 \\
-2 \cdot R\left(\bar{\omega}_{s, t}^{j}\right) \cdot \bar{\omega}_{s, t}^{j} ; s>64
\end{array}\right\}
$$

where $R(\cdot)$ is the statutory replacement rate function.

Budget balance for a self-financing PAYGO Social Security system with earmarked taxes at time $t$ requires: 


\section{Macro Effects}

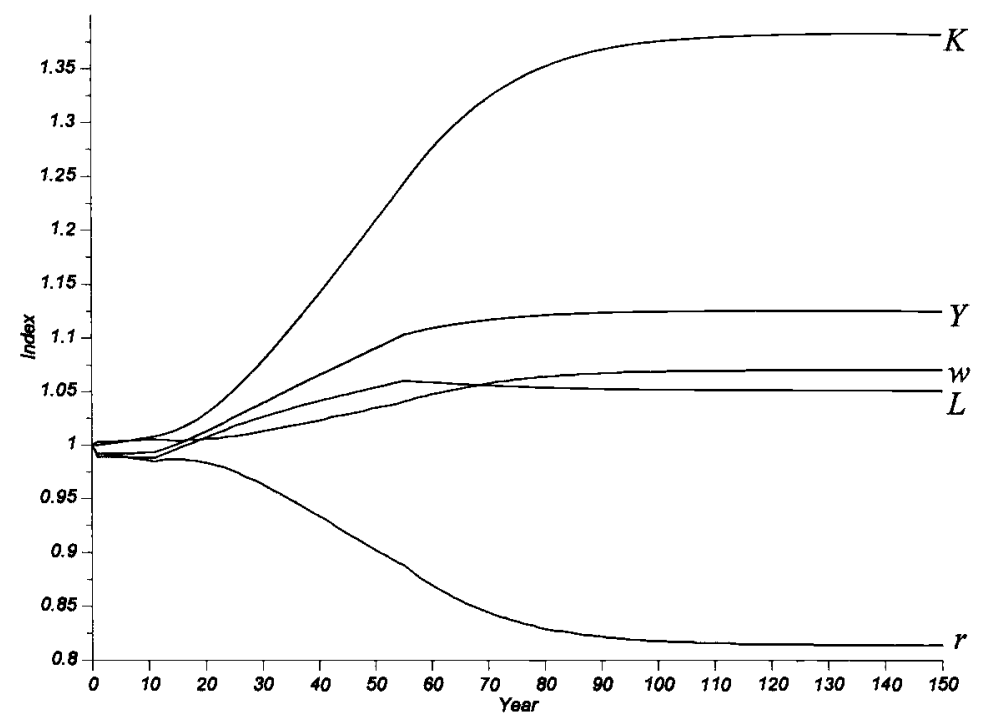

\section{Remaining Lifetime Utility}

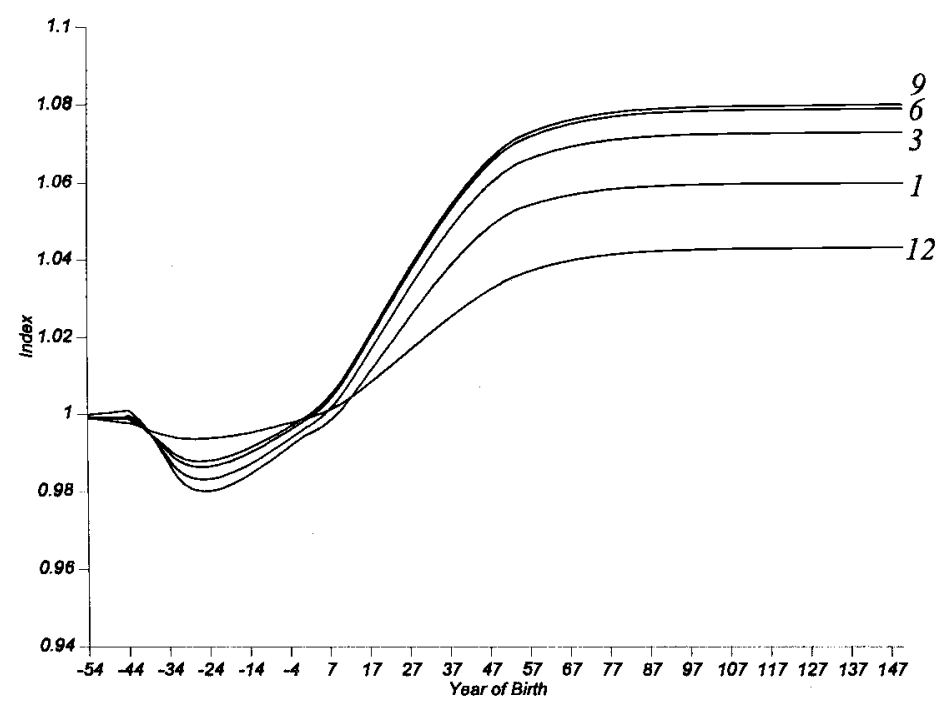

Fig. 8.1 Payroll tax finance of transition 


$$
\sum_{j=1}^{12} \phi^{j} \sum_{s=21}^{75}(1+n)^{-(s-21)} T^{P}\left(B_{s, t}^{j, P}\right)=0
$$

The value of $\tau$ is solved for endogenously as a function of benefit rules via equation (6). The value of $\tau$ is 9.9 percent in the initial steady state, which is close to its actual value in $1996 .{ }^{8}$

The net marginal tax rate is a component of the consumer's first-order conditions. Let $P V T\left(\omega_{s, t}^{j}\right)$ and $P V B\left(\omega_{s, t}^{j}\right)$ be the present value of payroll taxes and benefits, respectively, for the $j$-type agent age $s$ at time $t$. The net marginal tax rate for those below the earnings ceiling in each case considered herein is

$$
\begin{aligned}
\theta\left(\omega_{s, t}^{j}\right)= & \left\{\begin{array}{l}
\tau \cdot\left[1-\operatorname{PVB}^{\prime}\left(\omega_{s, t}^{j}\right) / \operatorname{PVT}^{\prime}\left(\omega_{s, t}^{j}\right)\right] ; \text { full perception linkage } \\
\tau ; \text { no perception linkage }
\end{array}\right\}
\end{aligned}
$$

where $P V B^{\prime}(\cdot)=\partial P V B(\cdot) / \partial \omega$ and $P V T^{\prime}(\cdot)=\partial P V T(\cdot) / \partial w \omega$. The simulations presented herein assume full perception - that is, that agents correctly foresee how the payroll taxes they pay relate to their future benefits. Simulations for the no-perception case can be found in Kotlikoff, Smetters, and Walliser (1999a). Under full perception, the net marginal tax rates are typically relatively higher for both richer and younger agents. The higher rates for richer agents reflect the progressive manner in which Social Security benefits are calculated. The higher rates for younger agents reflect the compound interest effect of being required to save in a Social Security system whose internal rate of return is less than after-tax rate of return to capital (reported below). Rich agents whose labor income exceeds the payroll tax face a zero marginal tax rate.

The HI and DI programs are modeled very simply. The HI and DI levels of lump-sum transfers are picked to generate payroll tax rates of 2.9 percent and 1.9 percent, respectively, corresponding to their 1996 statutory rates. Like the OASI taxes, DI contributions apply only to wages below $\$ 62,700$. The HI tax, in contrast, is not subject to an earnings ceiling. Lump-sum HI and DI benefits are provided on an equal basis to agents above and below age sixty-five, respectively. In the simulations using the new model, we have updated the payroll tax rates and payroll tax ceiling to their 1999 values.

\subsubsection{Aggregation and Technology}

Aggregate capital $(K)$ and labor $(L)$ are obtained from individual asset and labor supplies as

8. The employer-employee combined payroll tax equaled 10.52 percentage points. About 1 percentage point represents a net increase to the Social Security trust fund. 


$$
K_{t}=(1+n)^{t} \sum_{j=1}^{12} \phi^{j} \sum_{s=21}^{75}(1+n)^{-(s-21)} a_{s, t}^{j}-D_{t},
$$

(where, recall, $D_{t}$ is government debt at time $t$ ) and

$$
L_{t}=(1+n)^{t}(1+\lambda)^{-t} \sum_{j=1}^{12} \phi^{j} \sum_{s=21}^{75}(1+n)^{-(s-21)} \varepsilon_{s}^{j}\left(E_{s, t}^{j}-l_{s, t}^{j}\right) .
$$

Output (net of depreciation) is produced by identical competitive firms using a neoclassical, constant-returns-to-scale production technology. The aggregate production technology is the standard Cobb-Douglas form

$$
Y_{t}=A K_{t}^{\theta} L_{t}^{1-\theta},
$$

where $Y_{t}$ is aggregate output (national income) and $\theta$ is capital's share in production. Denote the capital-labor ratio as $\kappa$. The time- $t$ competitive posttax capital rate of return equals

$$
r_{t}=\frac{\theta A \kappa_{t}^{\theta-1}\left(1-\tau_{t}^{K}\right)+q_{t+1}-q_{t}}{q_{t}} .
$$

where $q_{t}=\left(1-z_{t} \tau_{t}^{K}\right)$ is Tobin's $q$ at time $t$ and $z$ is the level of capital investment expensing.

Given our parameter choices, the nondemographic version of the AKSW Model generates a pretax interest rate of 9.3 percent, a net national saving rate of 5.3 percent, and a capital/national-income ratio of 2.6. Consumption accounts for 73.4 percent of national income, net investment for 5.2 percent, and government purchases of goods and services for 21.4 percent. These figures are close to their respective 1996 NIPA values. The posttax interest rate equals 0.08 and is calculated following Auerbach (1996).

\subsubsection{Solving the Model}

The model uses a Gauss-Seidel algorithm to solve for the perfect foresight general equilibrium transition path of the economy. The calculation starts with a guess for certain key variables and then iterates on those variables until a convergence criterion is met. The solution involves several steps and inner loops that solve for household-level variables before moving to an outer loop that solves for the time paths of aggregate variables and factor prices.

Our optimization problem includes the constraint that leisure not exceed the endowment of time (equation [2]). For those households who would violate the constraint, the model calculates shadow wage rates at which they exactly consume their full-time endowment. The household's budget constraint is kinked due to the tax deductions applied against wage income. A household with wage income below the deduction level faces marginal and average tax rates equal to zero. A household with wage income above the deduction level faces positive marginal and average tax 
rates. Due to the discontinuity of the marginal tax rates, it may be optimal for some households to locate exactly at the kink. Our algorithm deals with this problem as follows. We identify households that choose to locate at the kink by evaluating their leisure choice and corresponding wage income above and below the kink. We then calculate a shadow marginal tax rate from the first-order conditions that puts those households exactly at the kink. This procedure generates optimal forward-looking leisure and consumption choices for all periods of life.

The payroll tax ceiling introduces additional complexity by creating a nonconvexity in the budget constraint. For those above the payroll tax ceiling, the marginal tax rate on labor falls to zero. We evaluate the utility on both sides of the nonconvex section and put households on the side that generates highest utility.

The sequence of calculations follows: An initial guess is made for the time paths of aggregate factor supplies as well as for the shadow wage rates; shadow tax rates; endogenous tax rates; the separate OASI, DI, and HI payroll tax rates; and the Social Security and Medicare wealth levels. The corresponding factor prices are calculated along with the forwardlooking consumption, asset, and leisure choices for all income classes in each current and future cohort. Shadow wages and shadow taxes are calculated to ensure that the time endowment and the tax constraints discussed above are satisfied. Households' labor supplies and assets are then aggregated by both age and lifetime income class at each period in time. This aggregation generates a new guess for the time paths of the capital stock and labor supply. The tax rate, which is endogenous for the particular simulation, is updated to meet the relevant revenue requirement. OASI, HI, and DI payroll tax rates are also updated to preserve the PAYGO financing of these benefits. ${ }^{9}$ The new supplies of capital and labor generated by the household sector of our model are weighted on an annual basis with the initial guess of these supplies to form a new guess of the time path of these variables. The algorithm then iterates until the capital stock and labor supply time paths converge.

\subsection{Simulation Results}

This section describes the results of six simulations. Additional simulations, which are presented in the next section, include some preliminary results of our model with enhanced demographics. The label "Year of Birth" in the tables and figures refers to the year of an agent's birth relative to the year the reform begins. Thus, for example, the index " -10 " refers to a person born ten years before the reform. The index "1" refers to a person born the year the reform begins.

9. Note that the Social Security replacement rate and absolute level of Medicare benefits are exogenous. 


\subsubsection{The Choice of the Tax Used to Privatize Social Security}

Simulations 1 through 3 study how different methods of financing the transition to a privatized Social Security system affect the macroeconomy, different cohorts, and different lifetime income classes within each cohort. In these simulations, participation in the new system is mandatory, and privatization entails (a) having workers contribute to private accounts, (b) paying retirees and workers in retirement those Social Security benefits that they had accrued as of the time of the reform, and (c) financing these accrued Social Security benefits during the transition with either a payroll tax, an income tax, or a consumption tax.

Since our model does not include liquidity constraints, privatizing Social Security contributions simply requires setting the model's Social Security payroll tax rate to zero. Since agents are able to borrow against any government-stipulated saving, there is no mechanical need to add a formal private pension system to the model to which workers are forced to contribute. Doing so would not change any agents' labor supply or consumption behavior. This said, it is worth noting that in the particular economies simulated here, only the poorest 10 percent of agents actually seek to borrow against their future Social Security benefits. Hence, prohibiting borrowing in our model would not materially alter our findings.

To provide existing retirees at the time of the reform their full accrued benefits, we wait ten years until after the reform is announced to start phasing out Social Security benefits. Since benefits in the economy's initial steady state are provided for the ten years between agents' ages forty-six and fifty-five, the ten-year delay in cutting benefits permits the ten initial generations of retirees to receive the same benefits they would have enjoyed absent the reform. Starting in the eleventh year of the reform, benefits are phased out by 2.2 percent (of the baseline benefits) per year for forty-five years. This phase-out pattern is designed to approximate the provision to initial workers of the full value in retirement of those benefits they had accrued as of the time of the reform.

In simulations 1 and 3, which use, respectively, a payroll tax and a consumption tax to finance benefits, the tax rates applied are proportional. Simulation 2 raises progressive income tax rates to finance transition benefits. This is accomplished by increasing the two components of the income tax, the progressive wage tax and the proportional capital income tax, so that the average wage tax and the average capital income tax change proportionally. The macroeconomic changes in factor supplies along the economy's transition path alter the income tax base used to finance government purchases. In order to maintain a constant level of government purchases per effective worker in each transition, we adjust income tax rates along the transition path even in those simulations in which income taxes are not used to pay the benefits accrued under Social Security. 


\section{Macroeconomic Effects}

The top panels of figures 8.1 through 8.3 and the first three rows of tables 8.1 through 8.5 show the macroeconomic impact of the three alternative methods of financing the transition. In tables 8.1, 8.2, and 8.3, the capital stock, labor supply, and output are measured per twenty-one-yearold. In simulations 1 through 6 , which are generated by our base model discussed above, the percentage changes are relative to the initial steadystate values of the variables in question.

The first thing to note is that all three simulations generate the same long-run outcome. This is to be expected, since in the long run Social Security is fully phased out and the tax used to pay for benefits during the transition equals zero. The long-run economic impact is considerable. Compared to the initial steady state, the economy's capital stock ends up 39.0 percent higher, its labor supply 5.5 percent higher, and its output 13.0 percent higher. The relative changes in factor supplies effect a 7.1 percent rise in the long-run real wage rate and an 18.6 percent decline in the interest rate.

Although all three policies do the same long-run macroeconomic good, they differ markedly with respect to their short-run macroeconomic impact and the speed with which they approach their common steady state. Consumption tax finance, by imposing a relatively heavy burden on the initial elderly (who have the highest consumption propensities due to their proximity to their terminal state), crowds in capital formation from the initiation of the reform onward. In contrast, wage taxation generates essentially no additional capital formation during the first decade of the policy. Indeed, even after twenty-five years, the capital stock is only 5.2 percent larger than its initial value. Income tax finance of the transition is even worse on this score. It actually reduces the capital stock for more than a quarter of a century after the reform begins. At the quarter-century mark, the capital stock is 4.6 lower than its starting value. The differences in these results are quite striking and serve as an important lesson to those advocating privatization. However, most proposals to privatize Social Security, which, incidentally, do not rely on consumption-tax finance, may still entail rapid attainment toward the new steady state if they phase out benefits under the old system at a faster rate. The trade-off, however, is that this might cause greater harm to initial retirees and workers.

\section{Welfare and Distributional Effects}

The bottom panels of figures 8.1-8.3 and the first three sections of table 8.6 show the winners and losers within and across generations of the three alternative ways of financing the transition. The first thing to note is that all agents alive in the long run, regardless of their lifetime income class, are better off as a result of Social Security's privatization. The welfare 


\section{Macro Effects}

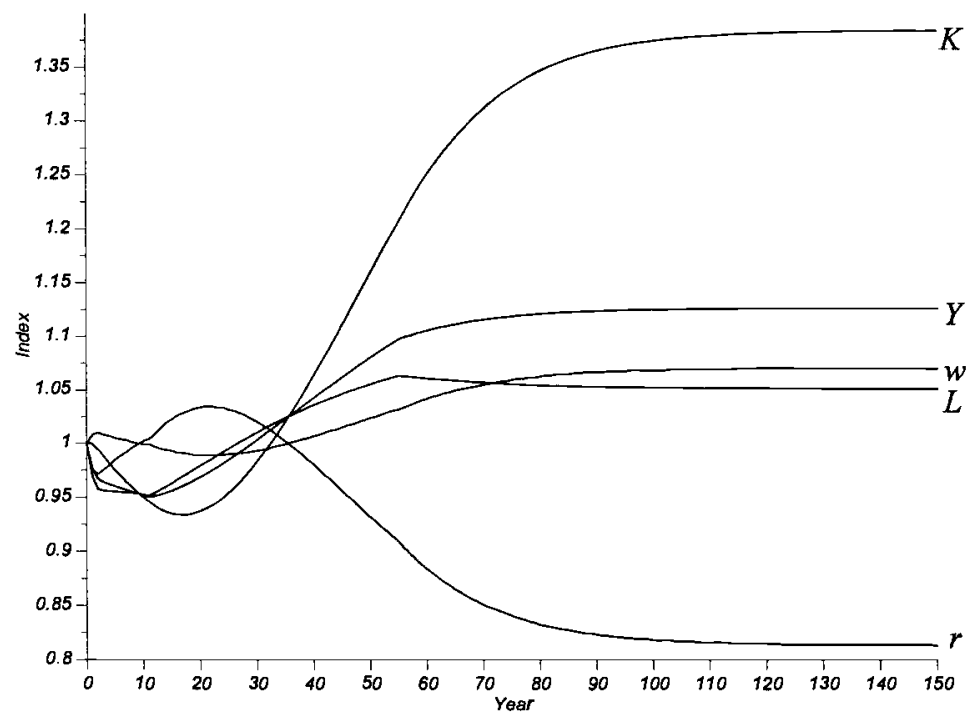

Remaining Lifetime Utility

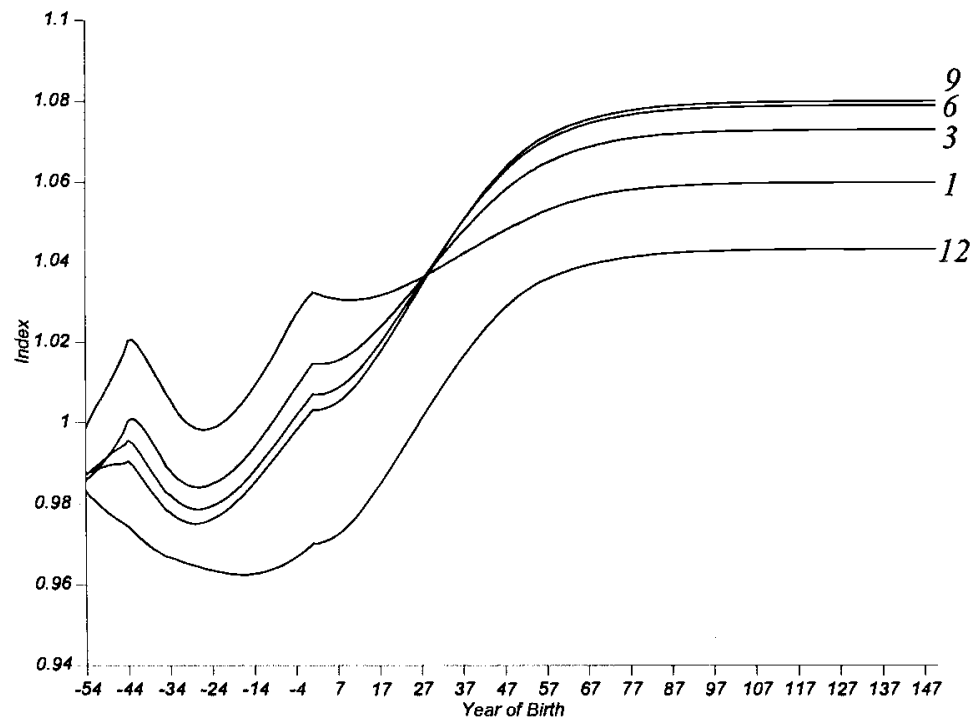

Fig. 8.2 Income tax finance of transition 


\section{Macro Effects}

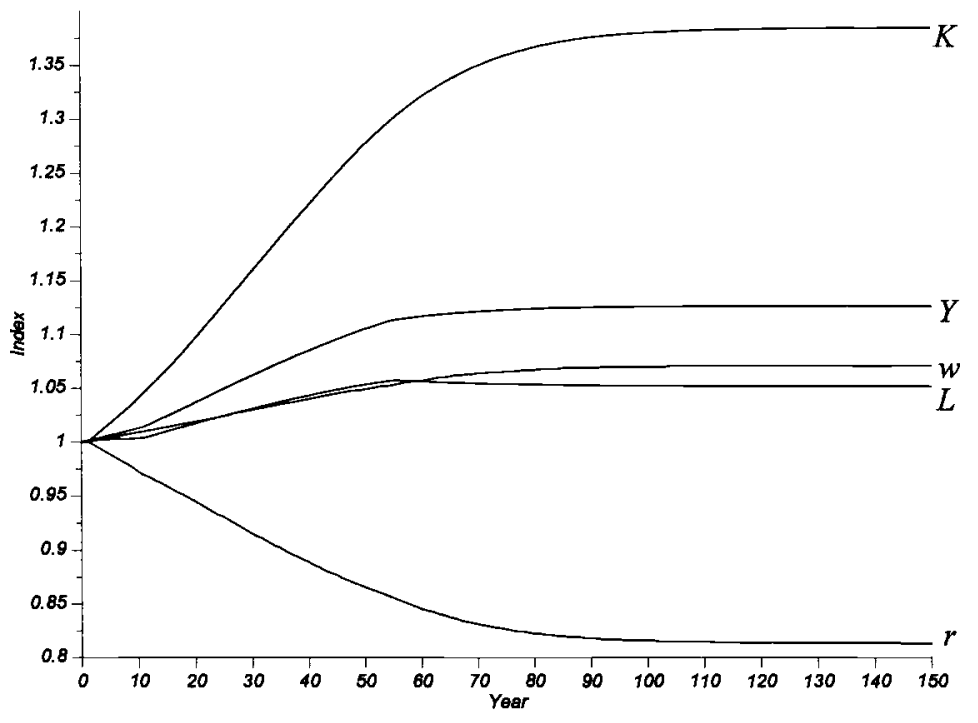

\section{Remaining Lifetime Utility}

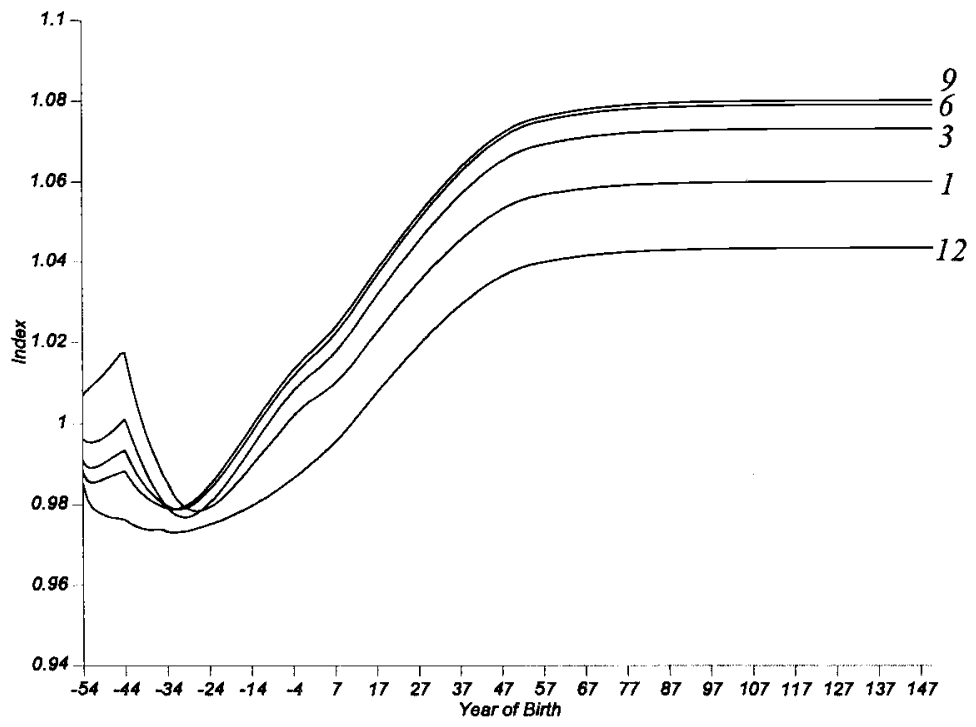

Fig. 8.3 Consumption tax finance of transition 
Percentage Change in Capital Stock

\begin{tabular}{|c|c|c|c|c|c|c|}
\hline \multirow[b]{2}{*}{ Run } & \multirow[b]{2}{*}{ Experiment } & \multirow[b]{2}{*}{ Transition Tax } & \multicolumn{4}{|c|}{ Year of Transition } \\
\hline & & & 5 & 10 & 25 & 150 \\
\hline 1 & Privatization & $\mathrm{W}$ & 0.0 & 0.1 & 5.2 & 39.0 \\
\hline 2 & Privatization & $\mathrm{Y}$ & -2.4 & -5.0 & -4.6 & 39.0 \\
\hline 3 & Privatization & $\mathrm{C}$ & 1.8 & 4.1 & 12.8 & 39.0 \\
\hline 4 & Voluntary privatization & $\mathrm{C}$ & 1.5 & 3.8 & 14.2 & 39.0 \\
\hline $4+$ & Voluntary privatization & $\mathrm{C}$ & 1.5 & 3.5 & 11.0 & 39.0 \\
\hline 5 & Privatization with flat benefit & $\mathrm{Y}$ & -2.8 & -5.7 & -8.7 & 12.4 \\
\hline 6 & $\begin{array}{l}\text { Privatization with progressive } \\
\text { match }\end{array}$ & $\mathrm{Y}$ & -3.4 & -7.1 & -9.7 & 35.4 \\
\hline $7^{*}$ & $\begin{array}{l}\text { Current policy in demo } \\
\text { model }\end{array}$ & $\mathrm{W}$ & 5.9 & 19.3 & 52.7 & 26.0 \\
\hline $8^{*}$ & Privatization in demo model & W & 6.9 & 21.9 & 61.8 & 112.1 \\
\hline
\end{tabular}

Notes: $\mathrm{C}=$ consumption tax. $\mathrm{W}=$ payroll tax. $\mathrm{Y}=$ income tax. All runs are relative to initial steady state except for starred runs, which are relative to year one.

Table 8.2

Percentage Change in Labor Supply

\begin{tabular}{|c|c|c|c|c|c|c|}
\hline \multirow[b]{2}{*}{ Run } & \multirow[b]{2}{*}{ Experiment } & \multirow[b]{2}{*}{ Transition Tax } & \multicolumn{4}{|c|}{ Year of Transition } \\
\hline & & & 5 & 10 & 25 & 150 \\
\hline 1 & Privatization & $\mathrm{W}$ & -1.1 & -1.1 & 1.8 & 5.5 \\
\hline 2 & Privatization & $\mathrm{Y}$ & -4.5 & -4.7 & 0.0 & 5.5 \\
\hline 3 & Privatization & $\mathrm{C}$ & 0.3 & 0.4 & 2.4 & 5.5 \\
\hline 4 & Voluntary privatization & $\mathrm{C}$ & -0.2 & 0.0 & 2.4 & 5.5 \\
\hline $4+$ & Voluntary privatization & $\mathrm{C}$ & 0.8 & 0.8 & 0.9 & 5.5 \\
\hline 5 & $\begin{array}{l}\text { Privatization with flat } \\
\text { benefit }\end{array}$ & $\mathrm{Y}$ & -4.7 & -4.9 & -2.9 & 1.2 \\
\hline 6 & $\begin{array}{l}\text { Privatization with } \\
\text { progressive match }\end{array}$ & Y & -6.7 & -7.3 & -3.0 & 4.0 \\
\hline $7 *$ & $\begin{array}{l}\text { Current policy in demo } \\
\text { model }\end{array}$ & $\mathrm{W}$ & -3.8 & -1.8 & 2.5 & -4.4 \\
\hline $8^{*}$ & $\begin{array}{l}\text { Privatization in demo } \\
\text { model }\end{array}$ & W & -3.6 & -1.6 & 5.4 & 5.0 \\
\hline
\end{tabular}

Notes: $\mathrm{C}=$ consumption tax. $\mathrm{W}=$ payroll tax. $\mathrm{Y}=$ income tax. All runs are relative to initial steady state except for starred runs, which are relative to year one.

gains - measured as full remaining lifetime wealth equivalent variationsvary from 6.0 percent for the lowest lifetime earners, to over 8 percent for the middle- and upper-income lifetime earnings, to only 4.4 percent for the highest lifetime earners. Hence, Social Security's privatization improves the welfare across all income classes for those born in the long run and is, broadly speaking, progressive when measured with respect to its 
Percentage Change in Income

\begin{tabular}{|c|c|c|c|c|c|c|}
\hline \multirow[b]{2}{*}{ Run } & \multirow[b]{2}{*}{ Experiment } & \multirow{2}{*}{$\begin{array}{c}\text { Tax that Finances } \\
\text { Accrued Social } \\
\text { Security Benefits }\end{array}$} & \multicolumn{4}{|c|}{ Year of Transition } \\
\hline & & & 5 & 10 & 25 & 150 \\
\hline 1 & Privatization & $\mathrm{W}$ & -0.8 & -0.7 & 2.6 & 13.0 \\
\hline 2 & Privatization & $\mathrm{Y}$ & -4.0 & -4.8 & -1.5 & 13.0 \\
\hline 3 & Privatization & $\mathrm{C}$ & 0.6 & 1.3 & 4.9 & 13.0 \\
\hline 4 & Voluntary privatization & $\mathrm{C}$ & 0.2 & 1.0 & 5.2 & 13.0 \\
\hline $4+$ & Voluntary privatization & $\mathrm{C}$ & 1.0 & 1.5 & 3.3 & 13.0 \\
\hline 5 & $\begin{array}{l}\text { Privatization with flat } \\
\text { benefit }\end{array}$ & $\mathrm{Y}$ & -4.2 & -5.1 & -4.4 & 3.9 \\
\hline 6 & $\begin{array}{l}\text { Privatization with prog } \\
\text { match }\end{array}$ & $\mathrm{Y}$ & -5.9 & -7.2 & -4.7 & 11.1 \\
\hline $7^{*}$ & $\begin{array}{l}\text { Current policy in demo } \\
\text { model }\end{array}$ & $\mathrm{W}$ & -1.5 & 3.1 & 13.3 & 2.4 \\
\hline $8^{*}$ & $\begin{array}{l}\text { Privatization in demo } \\
\text { model }\end{array}$ & $\mathrm{W}$ & -1.1 & 3.8 & 17.3 & 25.2 \\
\hline
\end{tabular}

Notes: $\mathrm{C}=$ consumption tax. $\mathrm{W}=$ payroll tax. $\mathrm{Y}=$ income tax. All runs are relative to initial steady state except for starred runs, which are relative to year one.

Table 8.4

Percentage Change in Wages

\begin{tabular}{|c|c|c|c|c|c|c|}
\hline \multirow[b]{2}{*}{ Run } & \multirow[b]{2}{*}{ Experiment } & \multirow{2}{*}{$\begin{array}{c}\text { Tax that Finances } \\
\text { Accrued Social } \\
\text { Security Benefits }\end{array}$} & \multicolumn{4}{|c|}{ Year of Transition } \\
\hline & & & 5 & 10 & 25 & 150 \\
\hline 1 & Privatization & W & 0.4 & 0.5 & 0.8 & 7.1 \\
\hline 2 & Privatization & $\mathrm{Y}$ & 0.5 & 0.0 & -1.0 & 7.1 \\
\hline 3 & Privatization & $\mathrm{C}$ & 0.4 & 0.9 & 2.4 & 7.1 \\
\hline 4 & Voluntary privatization & $\mathrm{C}$ & 0.4 & 0.9 & 2.8 & 7.1 \\
\hline $4+$ & Voluntary privatization & $\mathrm{C}$ & 0.2 & 0.7 & 2.4 & 7.1 \\
\hline 5 & $\begin{array}{l}\text { Privatization with flat } \\
\text { benefit }\end{array}$ & $\mathrm{Y}$ & 0.5 & -0.2 & -1.5 & 2.7 \\
\hline 6 & $\begin{array}{l}\text { Privatization with prog } \\
\text { match }\end{array}$ & $\mathrm{Y}$ & 0.9 & 0.1 & -1.8 & 6.8 \\
\hline $7^{*}$ & $\begin{array}{l}\text { Current policy in demo } \\
\text { model }\end{array}$ & $\mathrm{W}$ & 2.4 & 5.0 & 10.5 & 7.1 \\
\hline $8^{*}$ & $\begin{array}{l}\text { Privatization in demo } \\
\text { model }\end{array}$ & $\mathrm{W}$ & 2.6 & 5.4 & 11.3 & 19.2 \\
\hline
\end{tabular}

Notes: $\mathrm{C}=$ consumption tax. $\mathrm{W}=$ payroll tax. $\mathrm{Y}=$ income tax. All runs are relative to initial steady state except for starred runs, which are relative to year one.

long-run welfare effects. This may seem surprising, given that Social Security benefits are very progressive, and one might think that losing them should be very important to the lifetime poor. However, the opportunity cost of investing in Social Security is quite high even for a poor person because its internal rate of return is quite low relative to the private market return. Moreover, the system's taxes are regressive due to the ceiling on 


\begin{tabular}{|c|c|c|c|c|c|c|}
\hline \multirow[b]{2}{*}{ Run } & \multirow[b]{2}{*}{ Experiment } & \multirow{2}{*}{$\begin{array}{c}\text { Tax that Finances } \\
\text { Accrued Social } \\
\text { Security Benefits }\end{array}$} & \multicolumn{4}{|c|}{ Year of Transition } \\
\hline & & & 5 & 10 & 25 & 150 \\
\hline 1 & Privatization & $\mathrm{W}$ & -1.0 & -1.4 & -2.5 & -18.6 \\
\hline 2 & Privatization & $\mathrm{Y}$ & -1.5 & 0.0 & 3.2 & -18.6 \\
\hline 3 & Privatization & $\mathrm{C}$ & -1.1 & -2.7 & -6.9 & -18.6 \\
\hline 4 & Voluntary privatization & $\mathrm{C}$ & -1.2 & -2.7 & -7.8 & -18.6 \\
\hline $4+$ & Voluntary privatization & $\mathrm{C}$ & -0.5 & -1.9 & -6.8 & -18.6 \\
\hline 5 & $\begin{array}{l}\text { Privatization with flat } \\
\text { benefit }\end{array}$ & $\mathrm{Y}$ & -1.4 & 0.6 & 4.7 & -7.6 \\
\hline 6 & $\begin{array}{l}\text { Privatization with prog } \\
\text { match }\end{array}$ & $\mathrm{Y}$ & -2.6 & -0.2 & 5.4 & -17.9 \\
\hline $7 *$ & $\begin{array}{l}\text { Current policy in demo } \\
\text { model }\end{array}$ & $\mathrm{W}$ & -7.0 & -13.6 & -25.9 & -18.8 \\
\hline $8^{*}$ & $\begin{array}{l}\text { Privatization in demo } \\
\text { model }\end{array}$ & $\mathrm{W}$ & -7.5 & -14.8 & -27.5 & -41.1 \\
\hline
\end{tabular}

Notes: $\mathrm{C}=$ consumption tax. $\mathrm{W}=$ payroll tax. $\mathrm{Y}=$ income tax. All runs are relative to initial steady state except for starred runs, which are relative to year one.

Table 8.6

Percentage Change in Remaining Lifetime Utility for Selected Income Classes

\begin{tabular}{|c|c|c|c|c|c|c|c|}
\hline \multirow[b]{2}{*}{ Class } & \multicolumn{7}{|c|}{ Year of Birth } \\
\hline & -54 & -25 & -10 & 1 & 10 & 25 & 150 \\
\hline \multicolumn{8}{|l|}{ Run 1} \\
\hline 1 & 0.0 & -2.0 & -1.3 & -0.6 & 0.1 & 2.2 & 6.0 \\
\hline 3 & -0.1 & -1.7 & -1.1 & -0.4 & 0.5 & 3.0 & 7.4 \\
\hline 6 & -0.1 & -1.4 & -0.8 & -0.2 & 0.8 & 3.3 & 8.0 \\
\hline 9 & -0.1 & -1.2 & -0.7 & -0.1 & 0.9 & 3.5 & 8.1 \\
\hline 12 & -0.1 & -0.6 & -0.4 & -0.1 & 0.3 & 1.5 & 4.4 \\
\hline \multicolumn{8}{|l|}{ Run 2} \\
\hline 1 & -0.1 & -0.2 & 1.6 & 3.2 & 3.1 & 3.5 & 6.0 \\
\hline 3 & -1.4 & -1.6 & 0.0 & 1.4 & 1.7 & 3.3 & 7.4 \\
\hline 6 & -1.3 & -2.1 & -0.7 & 0.7 & 1.1 & 3.2 & 8.0 \\
\hline 9 & -1.2 & -2.4 & -1.0 & 0.3 & 0.8 & 3.1 & 8.1 \\
\hline 12 & -1.7 & -3.6 & -3.6 & -3.0 & -2.5 & -0.2 & 4.4 \\
\hline \multicolumn{8}{|l|}{ Run 3} \\
\hline 1 & 0.7 & -2.1 & -0.6 & 0.5 & 1.3 & 3.2 & 6.0 \\
\hline 3 & -0.4 & -2.0 & 0.0 & 1.2 & 2.1 & 4.2 & 7.4 \\
\hline 6 & -0.9 & -1.7 & 0.3 & 1.6 & 2.6 & 4.8 & 8.0 \\
\hline 9 & -1.2 & -1.6 & 0.5 & 1.7 & 2.7 & 4.9 & 8.1 \\
\hline 12 & -1.5 & -2.5 & -1.8 & -1.0 & -0.1 & 1.7 & 4.4 \\
\hline \multicolumn{8}{|l|}{ Run 4} \\
\hline 1 & 0.5 & -2.2 & -1.0 & 0.9 & 1.6 & 4.2 & 6.0 \\
\hline 3 & -0.3 & -2.7 & -0.2 & 1.6 & 2.4 & 5.2 & 7.4 \\
\hline
\end{tabular}

(continued) 
Table 8.6 (continued)

\begin{tabular}{|c|c|c|c|c|c|c|c|}
\hline \multirow[b]{2}{*}{ Class } & \multicolumn{7}{|c|}{ Year of Birth } \\
\hline & -54 & -25 & -10 & 1 & 10 & 25 & 150 \\
\hline 6 & -0.6 & -2.8 & 0.3 & 2.0 & 2.9 & 5.8 & 8.0 \\
\hline 9 & -0.8 & -2.8 & 0.5 & 2.2 & 3.1 & 5.9 & 8.1 \\
\hline 12 & -1.0 & -2.9 & -1.6 & -0.6 & 0.1 & 2.5 & 4.4 \\
\hline \multicolumn{8}{|c|}{ Run 4+ } \\
\hline 1 & 0.5 & -0.8 & -0.8 & 0.5 & 1.0 & 2.8 & 6.0 \\
\hline 3 & -0.2 & -1.3 & -0.5 & 1.2 & 1.8 & 3.8 & 7.4 \\
\hline 6 & -0.6 & -1.4 & 0.1 & 1.7 & 2.2 & 4.3 & 8.0 \\
\hline 9 & -0.8 & -1.4 & 0.3 & 1.8 & 2.4 & 4.4 & 8.1 \\
\hline 12 & -1.0 & -2.3 & -1.7 & -0.9 & -0.4 & 1.3 & 4.4 \\
\hline \multicolumn{8}{|c|}{ Run 5} \\
\hline 1 & -0.1 & 1.8 & 3.1 & 4.3 & 4.1 & 4.2 & 5.7 \\
\hline 3 & -1.4 & -0.5 & 0.6 & 1.7 & 1.7 & 2.3 & 4.8 \\
\hline 6 & -1.3 & -1.6 & -0.5 & 0.6 & 0.5 & 1.4 & 4.4 \\
\hline 9 & -1.2 & -2.1 & -1.0 & 0.0 & -0.1 & 1.0 & 4.1 \\
\hline 12 & -1.7 & -3.6 & -3.9 & -3.4 & -3.5 & -3.4 & 0.5 \\
\hline \multicolumn{8}{|c|}{ Run 6} \\
\hline 1 & -0.2 & 0.9 & 3.2 & 5.3 & 5.0 & 5.3 & 8.0 \\
\hline 3 & -1.8 & -1.3 & 0.7 & 2.6 & 2.7 & 4.2 & 8.4 \\
\hline 6 & -1.6 & -2.4 & -1.0 & 0.7 & 0.9 & 2.9 & 8.1 \\
\hline 9 & -1.6 & -3.2 & -1.8 & -0.4 & -0.1 & 2.2 & 7.7 \\
\hline 12 & -2.1 & -4.9 & -5.0 & -4.3 & -4.1 & -1.7 & 3.5 \\
\hline \multicolumn{8}{|c|}{ Run 8* } \\
\hline 1 & -0.01 & -2.36 & -2.29 & -1.49 & -0.88 & 2.11 & 7.68 \\
\hline 3 & 0.01 & -1.86 & -1.76 & -1.12 & -0.46 & 2.53 & 8.26 \\
\hline 6 & 0.02 & -1.41 & -1.22 & -0.57 & 0.25 & 3.47 & 9.60 \\
\hline 9 & 0.02 & -1.17 & -0.95 & -0.33 & 0.54 & 3.79 & 9.94 \\
\hline 12 & 0.03 & -0.37 & -0.18 & 0.06 & 0.45 & 1.89 & 5.99 \\
\hline
\end{tabular}

Note: All runs are relative to initial steady state except starred run, which is relative to utility under the current policy transition.

taxable earnings. The poor benefit more than the very rich from the privatization of Social Security because the regressiveness of the payroll tax outweighs the progressivity of the benefit schedule.

While everyone alive in the long run wins due to the privatization of Social Security, their winnings come at the price of reduced welfare for initial and intermediate generations. However, the different financing mechanisms spread out the transitional losses quite differently. Consumption tax financing (simulation 3) is hard on initial older generations because it raises resource using a wealth levy. Increasing progressive tax rates (simulation 2), however, hits them even harder. The wage tax transition is the least painful for the oldest retirees alive at the time of the reform, as they pay no wage taxes. Despite the fact that funding Social Security is simply a redistribution mechanism between generations that does not im- 
prove efficiency (that is, unless people do not perceive their Social Security tax-benefit linkage properly), it can be shown that greater funding can increase social welfare provided that the social welfare function places enough weight on the utility of future generations (Feldstein 1995, 1998). This is an important point for policy makers to keep in mind, because they influence the distribution of resources across generations.

\subsubsection{Making Privatization Voluntary}

A mandatory privatization plan may face less chance of being enacted than one that provides workers the choice to simply opt out of Social Security. Indeed, most actual privatizations have given people the choice. This was true, for example, in Chile and Argentina, and in the case of other major reforms in Latin America; only new workers were forced into the new system. In the United Kingdom, even new workers are allowed to choose between the traditional public pension system and private accounts. Allowing for choice leads those agents whose present values of future Social Security taxes (PVT) exceed the present value of their future benefits (PVB) (including benefits already accrued) to opt out of the existing system.

Permitting voluntary exit from Social Security involves three elements: (a) eliminating both future payroll taxation as well as all future benefit claims for those who opt out, (b) collecting payroll taxes from and paying benefits to those who stay in, and (c) using general revenue to finance the gap between payroll taxes collected and benefits received. Agents who stay in Social Security face the same payroll tax rate and receive the same benefits that they would under current law. Agents endogenously decide whether or not it is better for them to opt out of Social Security, taking into account the entire future path of factor prices and tax rates. Since the opting-out decision of one agent affects the decision of other agents via changes in factor prices, the simulation iterates until a final competitive (Nash) equilibrium is arrived at.

Providing workers with the option to leave Social Security may sound more generous than forcing them to leave with only their accrued benefits, but the opposite is actually the case. Consider first those who opt out of Social Security. In so doing, they forfeit all the benefits they have accrued up to that point in their working careers. Hence, compared with compulsory privatization, which guarantees the full value of accrued benefits, voluntary privatization is less generous. Next, consider those who decide to stay in the old system. In so doing, they ensure that they will receive their past accrued benefits (also provided by a compulsory system), but the price for so doing is staying in a system which, at the margin, may represent a net tax: For those remaining in the old system, each dollar contributed in the future may deliver additional benefits that total less than a dollar in expected present value.

In the actual simulation, the loss of their accrued benefits leads most 
existing workers to remain in the old system. On the other hand, all agents younger than twenty-five years of (real-life) age opt out, as do all future agents. Since the System's benefits are provided on a progressive basis, one would expect the opting-out cutoff age for high earners to be larger than that for low earners. This indeed turns out to be the case. High earners in their mid-thirties choose to opt out, whereas the poorest agents opt out only through age twenty-seven.

\section{Macroeconomic Effects}

To be sure, only a fraction of initial workers voluntarily leave the Social Security System under opting-out, which means that they will eventually collect full benefits, whereas they would have collected only partial benefits under the forced phase-out considered earlier. However, those that do leave forfeit their right to collect any future Social Security benefits, whereas they would have collected at least some benefits under the forced privatization plan considered earlier. On net, the aggregate decrease in Social Security wealth is about the same over time between the two options. This is shown in simulation 4 , which reports the results seen when agents are given the choice to remain in the current system or to opt out. The transition, which is depicted in figure 8.4, is financed via a consumption tax, similar to simulation 3 , that forces participation. Notice that the intermediate impact on macroeconomic variables is about the same for both simulations. For the case of income tax financing (not shown), opting out outperforms forced participation.

\section{Welfare and Distribution}

Compared with forced participation, opting out does a slightly better job of protecting the welfare of the initial elderly. Whereas the welfare of oldest agents alive at the time of the reform in income class 6 is reduced by 0.9 percent in simulation 3 , it is reduced by 0.6 percent in simulation 4. For members of income class 12 , who hold even more wealth and therefore are even more exposed to the wealth levy associated with consumption tax financing, these values are 1.5 percent and 1.0 percent, respectively. Opting out leads to a smaller need to increase consumption taxes immediately, because some payroll tax revenue is still being collected from those who remain in Social Security. Opting out, however, leaves middle-aged agents alive at the time of the reform (e.g., those born in year of birth -25) because many of them choose to remain in Social Security (and, therefore, pay a high payroll tax) and must help pay for, via a consumption tax, the revenue that is lost when younger and higher-earning workers opt out of Social Security.

To address the welfare impact that opting out has on middle-aged workers alive at the time of the reform, simulation $4+$ considers the same opting-out experiment but with a "plus": Workers who remain in Social Security must pay only half the current tax rate. The immediate payroll 


\section{Macro Effects}

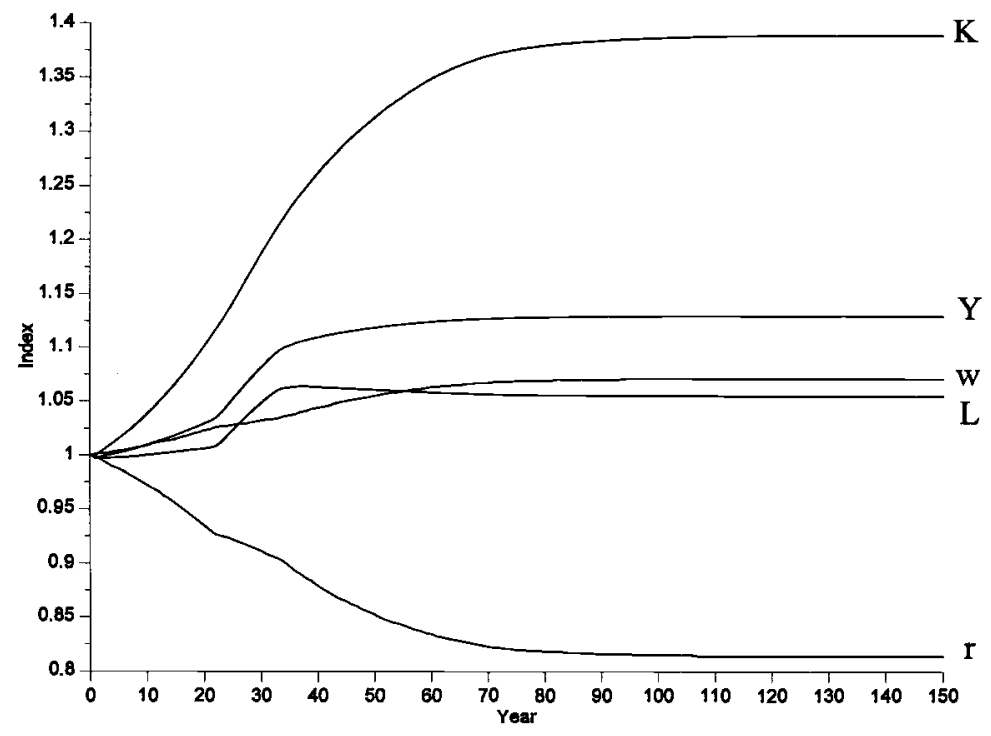

\section{Remaining Lifetime Utility}

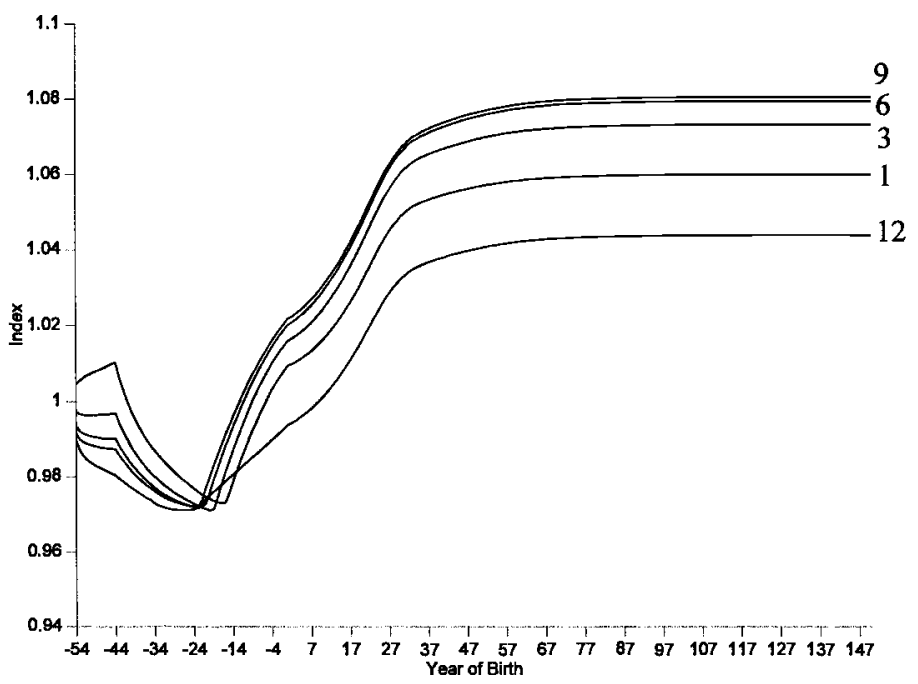

Fig. 8.4 Opting out with new payroll tax equal to present law value, consumption tax finance of transition 
tax revenue lost from this policy change is offset, in large part, by the decrease in the number of workers choosing to opt out. Eventually all new workers, however, choose not to participate in Social Security, even at a reduced payroll tax rate, because the rate of return they can receive in the capital market is sufficiently higher than the internal rate of return to Social Security. The net effect of this policy change is to reduce the revenue collected from those alive at the time of the reform and therefore push more of the burden toward future generations. This is why simulation 4+ leads to a slower transition relative to simulations 3 and 4, as shown in the tables. However, on the distributional side, simulation 4+ more evenly distributes the burden associated with privatization, both over time and across lifetime income groups. While the utility of a middle-aged agent (born in year -25) of income class 1 decreases by 2.1 percent in simulation 3 , it decreases by only 0.8 percent in simulation $4+$. This change comes, in part, at the cost of future transitional workers, who gain from privatization in both cases, but less so in simulation $4+$.

\subsubsection{Privatization with a Flat Benefit}

The World Bank has, in the past, encouraged developing countries to include a "first pillar" as part of their reforms. This first pillar is a flat benefit that is received by all workers independent of their contribution level. Although an attempt to protect the poor, the first pillar has two major drawbacks. First, the tax used for its finance adds a work disincentive. Second, the flat benefit is typically financed on a PAYGO basis and therefore vitiates most of the potential long-run gains from privatizing the old system. We investigate this policy by (a) providing a wage-indexed flat minimum annual benefit that equals $\$ 6,000$, (b) paying a weighted average of the old OASI and the new flat minimum benefit during the transition, and (c) financing the transition with a progressive income tax.

As tables 8.1 and 8.2 and figure 8.5 indicate, the long-run increases in capital and labor under this policy are less than one-third of their values in the absence of a flat minimum benefit. Furthermore, the added work disincentives associated with financing the minimum benefit reduce labor supply by almost 3 percent after the first twenty-five years of the transition, compared to no reduction for simulation 2. Less labor supply translates into less saving by workers, less national saving, and less domestic investment. Indeed, in the twenty-fifth year of this policy, the economy's capital stock and output are, respectively, 8.7 percent and 4.4 percent below their initial values.

How does adding a flat benefit to an income tax-financed policy alter the well-being of the poor in the long run? The surprising answer, provided in the fifth section of table 8.6, is that makes them worse off relative to privatization without the flat benefit. In the long run, the welfare of the poorest earners is 5.7 percent higher than in the initial steady state, 


\section{Macro Effects}

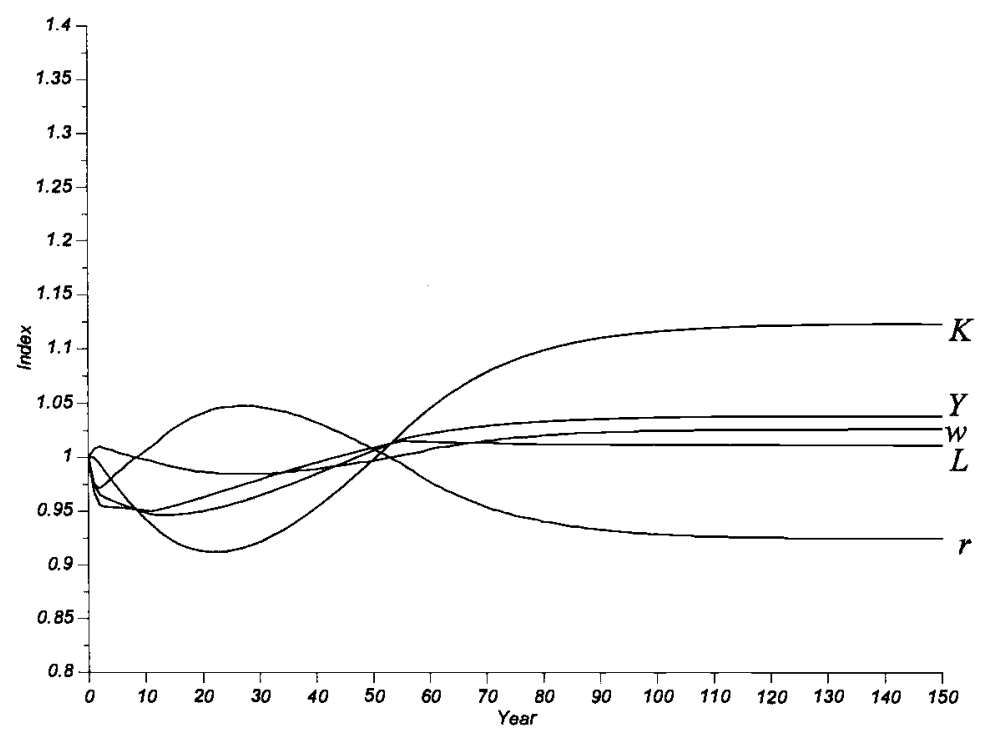

\section{Remaining Lifetime Utility}

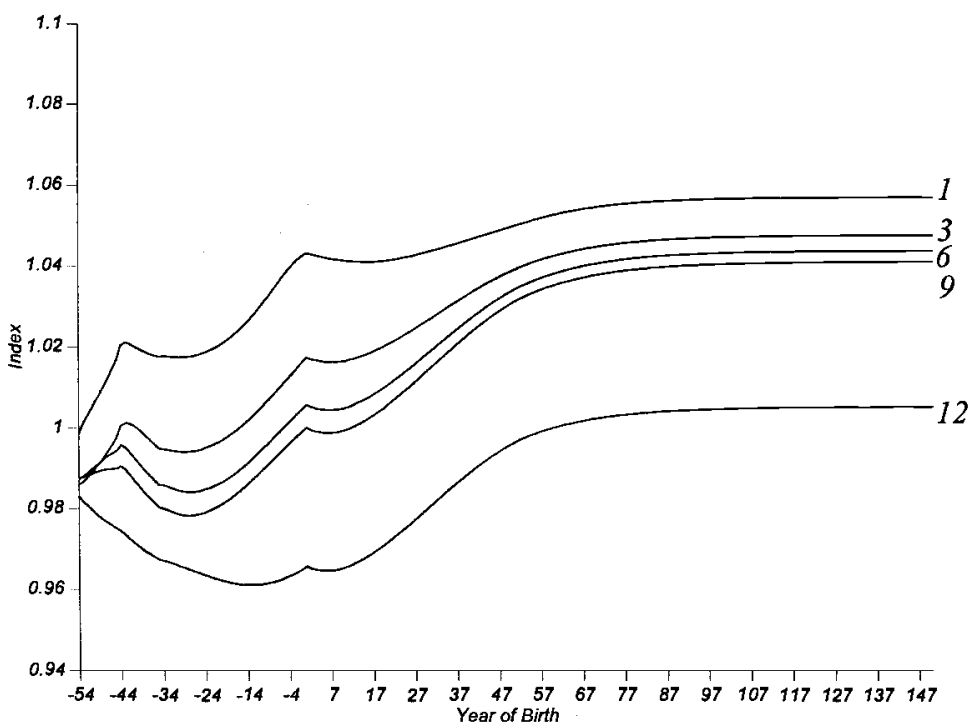

Fig. 8.5 Flat minimum benefit with income tax finance 
whereas without a flat benefit (simulation 2), it is 6.0 percent higher. Although the flat benefit harms the long-run poor, it substantially improves the well-being of the initial poor. For example, those members of the lowest earnings class who are born ten years before the policy is enacted enjoy a 3.1 percent improvement in welfare in simulation 5 compared to a 1.6 percent improvement in simulation 2. In contrast to the long-run poor, who are only mildly harmed by the flat benefit, the long-run middle class and rich are substantially harmed. For the long-run highest earners, welfare rises by only 0.5 percent in simulation 5 , compared to 4.4 percent in simulation 2. For those long-run members of earnings class 6 , the flat benefit lowers the welfare gain from 8.0 percent to 4.4 percent. To summarize, the inclusion of the flat benefit redistributes from those alive in the long run, but particularly from those with higher earnings, toward those who are poor during the transition.

\subsubsection{Privatization with a Progressive Matching Contribution}

The plan we consider in this section envisions having the government match contributions to the privatized system on a progressive basis. The government's match is calculated as a function of labor income and falls steadily as a percentage of earnings, starting at about 5 percent for the poorest. In absolute terms, it increases from about $\$ 470$ at annual earnings of $\$ 10,000$ to around $\$ 840$ for annual earnings of $\$ 21,000$ and remains constant thereafter. On a lifetime basis, the match provides a transfer to the poor whose long-run value exceeds the flat minimum benefit by 30 percent. Workers fully incorporate in their labor supply and saving decisions the marginal subsidy associated with the progressive contribution match. In order to compare the results of this option to those of the flat benefit, an income tax is used to finance the transition, including the match.

As tables 8.1 through 8.5 and figure 8.6 indicate, this method of helping the poor leads to the worst short-run macroeconomic outcomes of all the simulations presented thus far. By year twenty-five, the capital stock is smaller by 9.7 percent, labor is lower by 3 percent, and national income is down by 4.7 percent. However, unlike the flat benefit, whose general equilibrium feedbacks worsen the plight of the long-run poor, the progressive matching contribution raises their welfare by 8 percent in the long run. The primary sacrificers here are those in the top earnings classes of their respective cohorts.

The progressive match performs quite well when a consumption tax is used to finance the transition (which is not shown here in order to save space; see Kotlikoff, Smetters, and Walliser 1999a). All of the short-run and long-run gains to macroeconomic variables are positive and very similar to those shown in simulation 3, and the long-run gains are substantially larger relative to using a consumption tax to finance a flat benefit. For 


\section{Macro Effects}

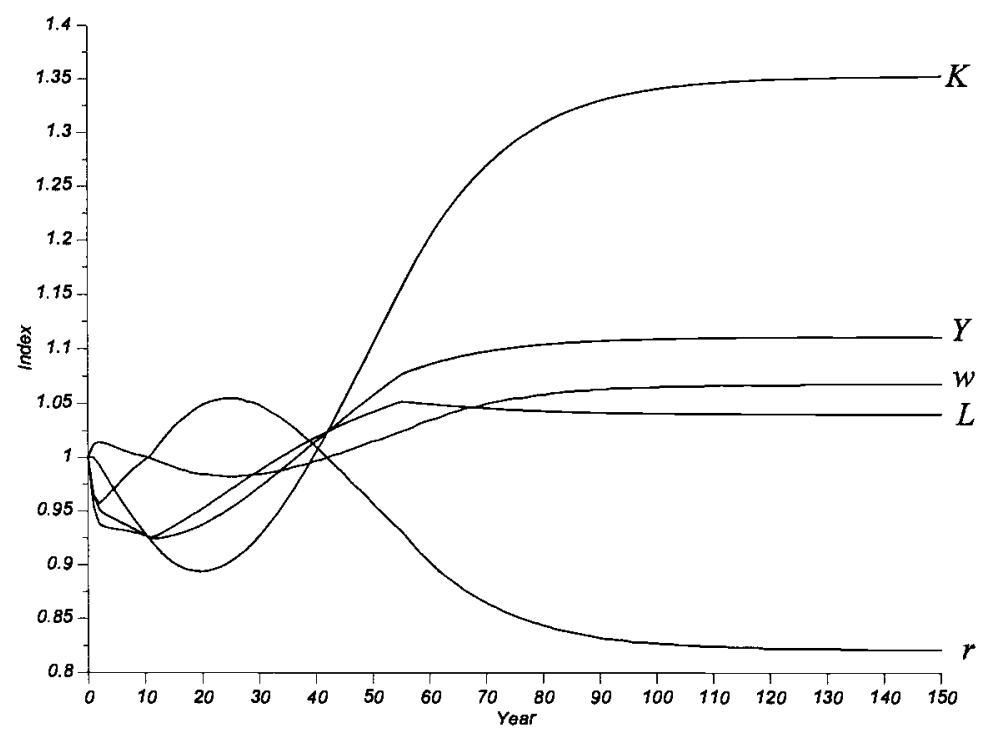

\section{Remaining Lifetime Utility}

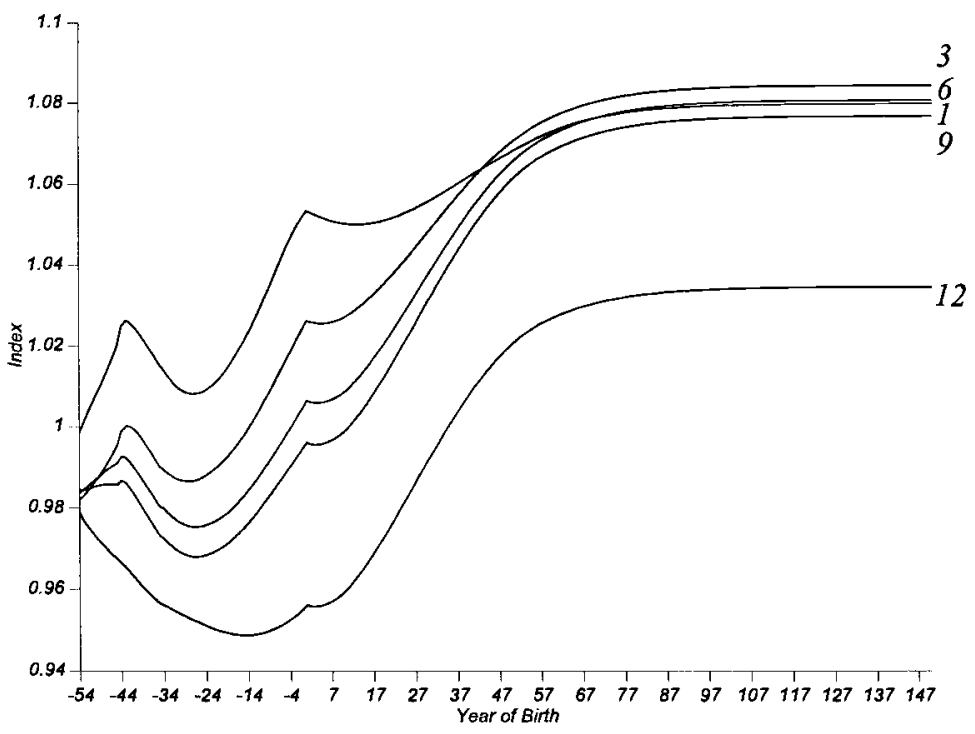

Fig. 8.6 Progressive match with income tax finance 
example, the capital stock increases by 39 percent under the progressive match but by only 23 percent under the flat benefit. For national income, these values are 12.4 and 7.5 percent, respectively. These results confirm the importance of the choice of the tax base used to finance the transition. They also indicate that there are ways to help the long-run poor without hurting those who are poor in the short run.

\subsection{Preliminary and Future Work: Including More Realistic Demographics}

This section outlines how we are currently modifying the model described in the previous section. We have already made a large amount of progress toward this end, but we are not yet satisfied enough with the model's design and calibration to regard our simulations as final. Hence, we offer the results in this section as a "sneak peek" - but a high-quality one-into our work at hand.

\subsubsection{The New Model}

Our current work expands the treatment of demographics in four dimensions. First, it permits much more realistic patterns of births. Second, it permits a more realistic length of life. Third, it permits a more realistic age-distribution of inheritances. Fourth, it permits the economy to initiate its transition from arbitrary initial demographic conditions; in other words, the initial period's population age distribution is not necessarily stable.

\section{Births and Children}

In the new version of the model, children derive utility from consumption and leisure from birth through age twenty-one. These levels of child utility enter their parents' utility function in a linearly additive manner. The form of this utility function is identical to that of the adults'. It is a time separable CES function and runs through the child's twenty-first year of age. The child utility functions are multiplied by a child-utility preference parameter. They are also multiplied by the number, which could be a fraction, of children per parent. Because parents give birth to children (or, to be more precise, give birth to fractions of children) at different ages, each parent's utility function has a child utility function for each of the different ages at which a child is born. Children are assumed to have a wage of zero prior to reaching age twenty-one. Consequently, they choose to supply no labor. On the other hand, they do consume when young. Their consumption is determined by their parents and enters their parents' budget constraints.

The new model features a realistic distribution of births by the age of parents instead of assuming that all children arrive when the parents reach age twenty-one. Newborns of each cohort are allocated to adults over age 
twenty-one based on the actual age-distribution of new mothers observed in U.S. data. For example, if thirty-year-old females give birth to 5 percent of newborns each year in the United States, 5 percent of the model's newborns each year are assigned as children to that year's thirty-year-olds. There is nothing in the mathematics of our model that precludes adults' giving birth to fractions of children in a given year. This allows us to avoid having to separately track those agents in a given cohort who do and do not have children in a given year. Instead, we can focus on the average agent in a particular income class and generation.

\section{Length of Life}

Average longevity in the United States has increased by about two years since the original Auerbach and Kotlikoff (1987) model and will continue to do so in the future. Thus, the fifty-five-period model, in which people are independent economic actors for fifty-five years, was updated to allow for sixty periods, or whatever age the programmer chooses. We are in the process of indexing this age to the year index, so that longevity can increase over time. We may also make longevity differ by income class if we can find suitable empirical data to match. As it stands now, an agent is an independent actor for sixty years, which means that agents live for a total of eighty-one years (the first twenty-one years as dependents).

\section{Inheritances}

A parent's utility from bequests is also modified in the new version of the model. Specifically, this utility is multiplied by the number of children the parent has when he or she reaches the maximum age of life and passes on. However, all recipients of bequests are no longer the same age. Instead, we assume that decedents divide their bequests evenly among all their offspring and that their offspring receive these inheritances at whatever age they have achieved as of the time of the parent's death.

\section{Calibration}

In calibrating the new model's demographics, we use the Social Security Administration's projections of aggregate annual births to determine the size of each successive cohort. In addition, we use the current age distribution of the U.S. population to populate our model in the first year of the transition. We do not assume a stable initial distribution of the U.S. population.

We have not yet calibrated the model to our full satisfaction. This includes fully matching the model's initial wealth and initial Social Security benefit distributions to their empirical counterparts. Some of the shortrun results presented below might reflect this fact, although the mediumto long-run results tend to be fairly robust to a reasonable range of choices for the model's initial conditions. Also, we currently assume that those in 
the top three lifetime income classes, representing the top 20 percent of the wage distribution, face only the inframarginal Social Security tax in each period of their lives; consequently, for this group, the marginal Social Security tax is always zero. All wage groups below the top three are assumed to face the Social Security tax rate at the margin. Although this assumption is likely to lead to very little bias, we plan to implement the procedure used in our base model in the near future that takes into account the kink in the budget constraint arising from the ceiling on payroll taxation. Finally, the aggregate variables produced by our model are measured per twenty-one-year-old. That is, they are normalized by the number of agents who are who are entering their first year of independent economic activity.

\subsubsection{Preliminary Simulation Results}

\section{Simulating the Demographic Transition Under Current Policy}

Simulation 7 considers how the Social Security system will fare over time if there is no change in the PAYGO nature of the program. Given the projected aging of the U.S. economy and the concomitant projected growth in Social Security benefits, Social Security payroll tax rates will have to rise if no other financing mechanism is put into place. Indeed, simulation 7, entitled "Current Policy in Demo Model," eventuates in a 5 percentage point rise in the payroll tax rate. This is the bad news about the demographic transition. The good, and somewhat surprising, news is that, notwithstanding Social Security's problem, the nation's aging is a positive thing for the economy overall if we look out to the medium term. Table 8.3 documents this point. It shows that output per twenty-one-yearold is 2.5 percent lower five years from now (year 1 in the simulation), but 12.9 percent higher twenty-five years from now. In the very long run, after the nation's population distribution has stabilized, output per twenty-oneyear-old is only 3.3 percent higher than its current value.

The explanation for this unusual growth pattern is the medium-term capital deepening arising from the large numbers of baby boomers arriving at retirement with significant holdings of capital. Since the work force coming behind them is relatively small in size, there is a substantial rise in the capital-labor ratio. For example, in the twenty-fifth year of the transition, the capital-labor ratio is 47 percent higher than its initial value. This capital deepening translates into almost a 10 percent rise in the real wage in the medium term and an 8 percent rise in the real wage in the long term.

\section{Privatization in the Demographic Model}

Our final simulation, number 8 , enacts the privatization policy of simulation 1 . Social Security benefits are phased out after ten years, and transi- 
tion costs are financed with a proportional labor tax on wages. As tables 8.1 through 8.5 indicate, compared to the status quo/current policy transition (simulation 7), privatization in the demographic model (simulation 8) produces an even more dramatic improvement in the economy's mediumas well as long-run positions. According to table 8.3 and the top panel in figure 8.7 , privatization raises living standards twenty-five years out by 18.8 percent, and in the long run by 20 percent. Associated with this policy is a 56 percent increase in the capital-labor ratio by year 25 and a corresponding 11.1 percent rise in real wages. The combination of capital deepening and reduced payroll taxation generates a significant medium-term increase in labor supply. In year 25, labor supply is 7.0 percent above its initial (year 1) value, compared to only 2.7 percent above in the currentpolicy demographic simulation.

Table 8.6 and figure 8.7 display the welfare effects associated with privatization using wage-tax finance. Welfare changes are measured relative to the utility levels that the particular agents in each generations would have enjoyed under the status-quo (baseline) policy, which is considered in simulation 7. There are four things here worth emphasizing. First, as in the nondemographic version of our model (see simulation 1), all lifetime earnings groups alive in the long run experience substantial welfare gains from Social Security's privatization. Second, the lifetime poor alive in the long run experience a much higher welfare gain than do the lifetime rich. Third, these long-run gains are larger in the nondemographic model because the long-run payroll tax rate would otherwise be 5 percentage points higher. Fourth, the short-run welfare losses to initial younger workers are larger in the demographic model because of the need to pay the retirement benefits of the large baby boom cohorts.

\subsection{Conclusion}

The U.S. Social Security system is in trouble. Its projected future expenditures exceed its projected means of paying for those expenditures by more than one-third. Addressing Social Security's fiscal imbalance is inevitable. How it is done will affect current and future generations of Americans, not just through their payment of payroll taxes and their receipt of benefits, but also through the real wages and real rates of return they earn on their labor supply and savings. Hence, understanding these effects necessitates a general equilibrium analysis. This paper provides such an analysis. It shows that privatizing Social Security can generate significant longrun economic gains for the lifetime poor as well as the lifetime rich. However, achieving these gains comes at the expense of some welfare losses to transition generations. It also requires patience, since even the bestdesigned privatization of Social Security will take years to significantly 


\section{Macro Effects}

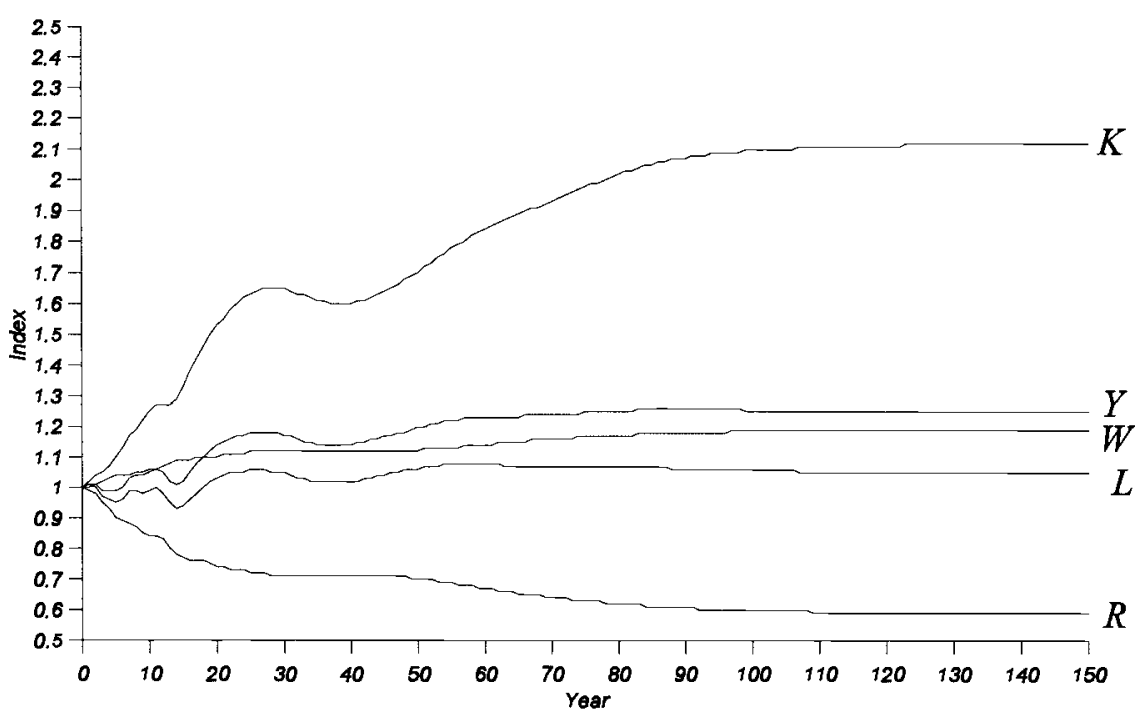

\section{Remaining Lifetime Utility}

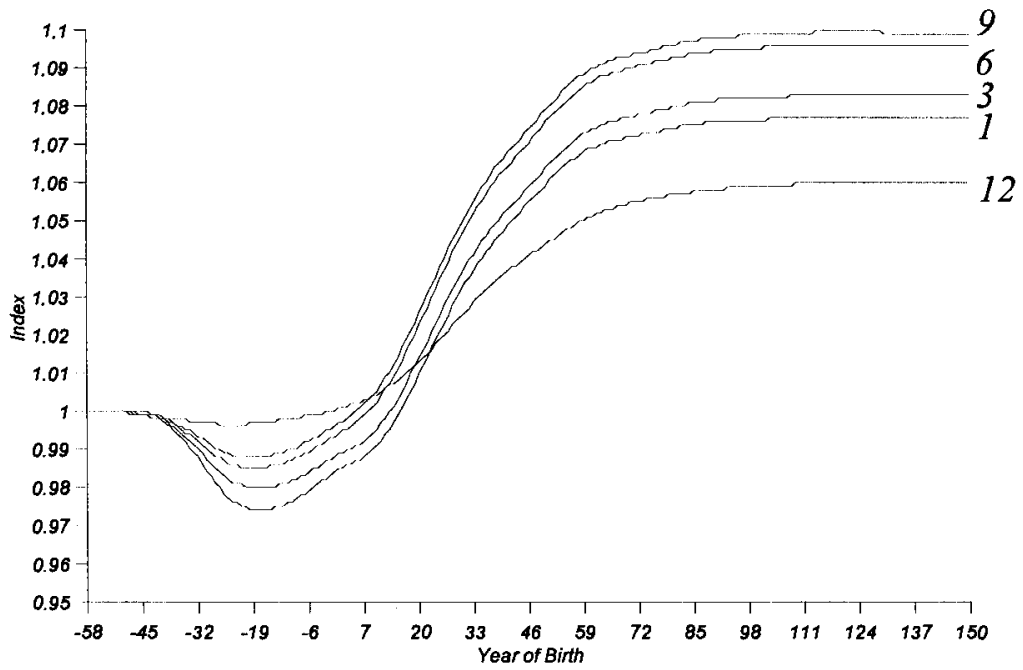

Fig. 8.7 Payroll tax finance of transition (demo) 
affect the economy. Finally, it requires avoiding flat benefits and other measures that may seem progressive but that end up doing more harm than good to those who are poor in the long run.

\section{References}

Altig, David, Alan Auerbach, Larry Kotlikoff, Kent Smetters, and Jan Walliser. 2001. Simulating U.S. tax reform. American Economic Review 91 (3): 574-95.

Arrau, Patricio, and Klaus Schmidt-Hebbel. 1993. Macroeconomic and intergenerational welfare effects of a transition from pay-as-you-go to fully funded pensions. Paper of the Policy Research Department, Macroeconomics and Growth Division. Washington, D.C.: World Bank.

Auerbach, Alan J. 1996. Tax reform, capital accumulation, efficiency, and growth. In Effects of Fundamental Tax Reform, ed. Henry J. Aaron and William G. Gale, 29-82. Washington, D.C.: Brookings Institution.

Auerbach, Alan J., and Laurence J. Kotlikoff. 1983. National saving, economic welfare, and the structure of taxation. in Behavioral simulation methods in tax policy analysis, ed. Martin S. Feldstein, 459-93. Chicago: University of Chicago Press. Press.

1987. Dynamic fiscal policy. Cambridge, England: Cambridge University

Auerbach, Alan, Robert Hageman, Laurence J. Kotlikoff, and Giuseppe Nicoletti. 1989. The economics of aging populations: The case of four OECD economies. OECD Staff Papers.

Cooley, Thomas F., and Jorge Soares. 1999a. A positive theory of Social Security based on reputation. Journal of Political Economy 107 (1): 135-60. 731-55.

De Nardi, Mariacristina, Selahattin İmrohoroğlu, and Thomas J. Sargent. 1999. Projected U.S. demographics and social security. Review of Economic Dynamics 2 (3): 575-615.

Feldstein, Martin S. 1974. Social Security, induced retirement, and aggregate capital accumulation. Journal of Political Economy 82:905-26.

1995. Would privatizing Social Security raise economic welfare? NBER Working Paper no. 5281. Cambridge, Mass.: National Bureau of Economic Research.

1998. Introduction to Privatizing Social Security, ed. Martin S. Feldstein, 1-29. Chicago: University of Chicago Press.

Fougere, Maxime, and Marcel Merette. 1998. Economic dynamics of population aging in Canada: An analysis with a computable overlapping-generations model. Paper presented at the Canadian Public Economics Study Group, Ottawa, Canada. May.

1999. Population aging, intergenerational equity and growth: Analysis with an endogenous growth, overlapping generations model. In Using dynamic general equilibrium models for policy analysis. ed. Glenn W. Harrison, Svend E. Hougaard Jensen, Lars Haagen Pedersen, and Thomas F. Rutherford, 13-52, 325-362. Amsterdam: North Holland.

Fullerton, Don, and Diane Lim Rogers. 1993. Who bears the lifetime tax burden? Washington, D.C.: Brookings Institution. 
Galasso, Vincenzo. 1999. The U.S. Social Security system: What does political sustainability imply? Review of Economic Dynamics 2 (3): 698-730.

Hansson, Ingemar, and Charles Stuart. 1989. Social Security as trade among living generations. American Economic Review (December): 1182-95.

Huang, He, Selo İmrohoroğlu, and Thomas Sargent. 1997. Two computational experiments to fund social security. Macroeconomic Dynamics 1:7-44.

Hubbard, Glenn R., and Kenneth L. Judd. 1987. Social Security and individual welfare: Precautionary saving, borrowing constraints, and the payroll tax. The American Economic Review 77 (4): 630-46.

- 1994a. The importance of precautionary motives in explaining individual and aggregate saving. Carnegie-Rochester Conference Series on Public Policy 40:59-125. 174-79.

1995. Precautionary saving and social insurance. Journal of Political Economy 103 (2): 360-99.

Huggett, Mark, and Gustavo Ventura. 1999. "On the Distributional Effects of Social Security Reform,” Review of Economic Dynamics, 2(3), July, 498-531.

İmrohoroğlu, Ayse, Selahattin İmrohoroğlu, and Douglas H. Joines. 1995. A life cycle analysis of social security. Economic Theory 6:83-114b.

1999. Social security in an overlapping generations economy with land. Review of Economic Dynamics 2 (3): 638-65.

Kotlikoff, Laurence J. 1979. Social security and equilibrium capital intensity. Quarterly Journal of Economics (May): 233-54.

. 1996. Privatizing social security: How it works and why it matters. In Tax policy and the economy, Vol. 10, ed. James M. Poterba, 1-32. Cambridge, Mass.: MIT Press.

Kotlikoff, Laurence J. 2000. The A-K model: Its past, present, and future. In Using dynamic general equilibrium models for policy analysis, forthcoming, ed. Glenn W. Harrison, Svend E. Hougaard Jensen, Lars Haagen Pedersen, and Thomas F. Rutherford, 13-52. Amsterdam: North Holland.

Kotlikoff, Laurence J., Kent Smetters, and Jan Walliser. 1997. The economic impact of privatizing Social Security. In Redesigning social security, ed. Horst Siebert. 327-48. Tübingen, Germany: Mohr Siebeck.

. 1998a. Opting out of social security and adverse selection. NBER Working Paper no. 6430. Cambridge, Mass.: National Bureau of Economic Research, February.

1998b. Social security: Privatization and progressivity. Papers and Proceedings of American Economic Review 88 (2): 137-41.

. 1999a. Privatizing social security in the U.S.: Comparing the options. Review of Economic Dynamics 2 (3): 532-74.

. 1999b. Privatizing U.S. Social Security: A simulation study. In Pension systems: From crisis to reform, ed. Klaus Schmidt Hebbel. Washington, D.C.: World Bank. Forthcoming.

Knudsen, Martin B., Lars Haagen Pedersen, Toke Ward Petersen, Peter Stephensen, and Peter Trier. 1999. A dynamic CGE analysis of the Danish aging problem. In Using dynamic computable general equilibrium models for policy analysis. North Holland. Forthcoming.

Menchik, Paul L., and Martin David. 1982. The incidence of a lifetime consumption tax. National Tax Journal 35 (2): 189-203.

Raffelhuschen, Bernd. 1993. Funding social security through pareto-optimal conversion policies. In Public pension economics, ed. Bernhard Felderer, 105-31. Journal of Economics/Zeitschrift fur Nationalokonomie, Suppl. 7. 
Schneider, Ondrei. 1997. Dynamic simulation of pension reform. Charles University, CERGE-EL, Prague. Mimeograph.

Seidman, Laurence S. 1986. A phase-down of social security: The transition in a life cycle growth model. National Tax Journal, 39:97-107.

Slemrod, Joel, and Jon M. Bakija. 1996. Taxing ourselves: A citizen's guide to the great debate over tax reform. Cambridge, Mass.: MIT Press.

World Bank. 1994. Averting the old age crisis. Washington, D.C.: World Bank.

\section{Comment James E. Duggan and David W. Wilcox}

The paper by Kotlikoff, Smetters, and Walliser (KSW) represents a progress report on - and an extension of - a research program of very impressive proportions. Surely, this must be one of the most ambitious simulation research programs in economics, whether measured in terms of the importance of the topic, the length of time that the authors have remained with the project, or the range of features they have incorporated into their model.

We organize our comment into two main sections. First, we highlight three specific observations about various aspects of the paper. Then we move to a more general assessment of the adequacy of the basic approach used by KSW - and countless others - as a means of conducting distributional analysis of the Social Security system.

\section{Specific Observations}

It is ironic that the last time one of us (Wilcox) had the pleasure of serving as a discussant at an NBER conference, it was also of a Smetters paper, the objective of which was to highlight the financial risk associated with ownership of equities. In particular, the earlier Smetters paper argued that the burden of equity-related risk should be evaluated at the prices paid by private market participants. Given the important role that equities play in the current paper, and the striking results reported in the earlier paper, future effort might be directed toward examining whether additional insights could be gained by marrying these two branches of Smetters's research.

A second observation pertains to the use of the word "privatization" in this paper. The positive welfare effects that obtain in the new steady state do not stem from linking an individual's Social Security benefit to the

The views expressed in this note are those of the authors and may not reflect the official views of the Treasury Department. The authors thank John Hambor and Chris Soares for helpful discussions.

James E. Duggan is a senior economist in the Office of Economic Policy at the U.S. Treasury Department. David W. Wilcox is deputy director in the Division of Research and Statistics at the Federal Reserve Board. 
investment outcome of an account in that person's name and under his or her individual control. Rather, the welfare benefits simply reflect the result demonstrated by Peter Diamond (1965), that when the economy is on the right side of the golden rule, steady-state utility is higher in a funded system than in an unfunded system. In short, the welfare gains estimated by KSW have nothing to do with "privatization" as most people understand that term, and all of the benefits outlined by KSW could equally be captured in a prefunded system that preserves the essential contours of the current system. ${ }^{1}$

Finally, we question the characterization of some of the results as demonstrating that "privatization" is "progressive" (see, for example, the discussion of table 8.6 in section 8.4). It is true that, in most or all of these simulations, the poor are better off by more than the top 2 percent of the population, but they are also better off by less than everyone else for whom results are shown. This does not answer to our definition of a progressive reform.

\section{The More General Question}

In the remainder of this comment, we focus on one element of KSW's model, namely the representation in the model of the mechanism that generates Social Security benefits. The goal will be to assess the adequacy of the approach taken by KSW, using some administrative data available to us at the Treasury Department. KSW have enforced some simplifications of reality, with the objective of keeping the model computationally and conceptually tractable. The important question is not whether the model is simpler than reality - it is - but, rather, whether the simplifications could materially affect the conclusions of some analyses KSW might undertake in the future, recognizing that (a) the authors intend to use the model to address questions in which general-equilibrium considerations may be particularly germane, and (b) they also intend to examine (as the title of their paper states) the distributional effects of various policy experiments.

One common approach in setting up a simulation model is to specify a small number of worker/beneficiaries, each with an exogenous earnings trajectory. This is the approach that historically has been taken, for example, by the Social Security actuaries, with their "steady low earners," "steady average earners," and "steady high earners."

KSW go one better than this by specifying the lifetime skill profiles of a small number of worker/beneficiaries as well as their preferences over consumption and leisure. Importantly, this allows labor supply to respond endogenously to changes in factor prices. Nonetheless, individuals with

1. See Geanakoplos, Mitchell, and Zeldes (1998) for a careful typology of Social Security systems and reforms. 
the preferences assumed by KSW will always choose at least some work (assuming a positive wage rate) and will experience a smooth earnings trajectory over their lifetimes, much like the ones specified by the actuaries.

Weaknesses of the Typical Approach

At least in its simplest form, the approach taken by KSW and countless other authors suffers from some notable shortcomings, at least for some purposes: It cannot be used to analyze issues related to gender, because there is (in the simplest models) no distinction between males and females. Likewise, it cannot be used to analyze issues related to survivor benefits, because there is no concept of premature death. Nor can it be used to analyze issues related to spousal benefits, because there is no concept of marriage.

Even the ability to examine issues related to income may be more limited than it first appears. For example, labor force attachment is markedly more intermittent for lower-income workers than for higher-income workers, yet, in the typical approach, all earnings trajectories show each worker/beneficiary with positive earnings every year of working life. Depending on the question under investigation, this could be a material shortcoming.

\section{Solutions to These Problems}

All of the issues raised above could be addressed by increasing (possibly greatly) the number of earnings trajectories considered. For example,

- To address the issue of gender, one could double the number of trajectories and label half as "women" and the other half as "men."

- To address the issue of survivor benefits, one could impose an empirically realistic distribution of death dates for each gender. Some workers would die young, some at intermediate ages, and some in old age.

- To address the issue of spousal benefits, one could allow an empirically realistic amount of "marriage" to take place, with an appropriate matching of age and lifetime-income characteristics.

The proper means of addressing the issue of intermittent labor force attachment is less apparent, but a good start might involve building in the idea that, for many workers, employment is more a binary variable than continuous. The modifications that are advertised at the end of the paper are interesting and useful, but will not fundamentally address any of the issues raised here.

\section{Evaluating the Seriousness of the Problem}

Do the simplifications inherent in the baseline model involve important loss of accuracy in answering specific questions? The remainder of this comment provides some evidence on that question. The results that follow 
are based on two primary data files from the Social Security Administration (SSA): the 1 percent 1996 Continuous Work History Sample (CWHS) and the Master Beneficiary Record (MBR). The CWHS is a record of 1951-96 annual earnings for workers in covered employment, and the MBR is a record of benefits paid to those workers when they retire (or become disabled) and to nonworkers who become eligible on the basis of a worker's eligibility (spouses, children, etc.). We also utilize data on the earnings histories of auxiliary beneficiaries extracted from SSA's Master Earnings File.

We formed a subsample of just over 95,000 retired-worker (76 percent), spouse (11 percent), and widow (13 percent) beneficiaries born during the years 1924 to 1928. In the spirit of KSW, we classified observations according to the distribution of age-sixty-five benefits. For those beneficiaries who died before age sixty-five, or who started receiving benefits after age sixty-five, we imputed an age-sixty-five benefit by indexing the benefit closest to that age based on legislated changes in benefits. Our benefit classification scheme mimics the twelve KSW income categories: the first two percentiles, the next eight percentiles, deciles two to nine, the 91st-98th percentiles, and the top two percentiles. The second column of table 8C.1 shows the means and standard deviations of age-sixty-five benefits for retired workers by benefit class. (For purposes of this table we omitted spouses and widows.)

The third column shows, for the same subsample, the benefit amounts that would be paid based on the mean earnings trajectory for each benefit class. The greatest discrepancies between the second and third columns occur at the lower and top benefit classes.

It is interesting to note that the benefit classes are demographically very nonhomogeneous. For example, figure 8C.1 shows the distribution of males and females by benefit class based on actual benefits. Most women are in the lower end of the distribution and most men in the upper end. This suggests that Social Security reforms that affect different income classes differently will also affect men and women differently.

We constructed age-earnings profiles for the beneficiary sample described above for ages twenty-five to sixty-five using actual historical covered earnings data from the CWHS for primary workers and from the SSA's Master Earnings File for auxiliary beneficiaries. Figure 8C.2 shows these profiles for three beneficiary classes, the first two percentiles, the 5th decile, and the top two percentiles. The differences in magnitude and shape are remarkable, even if expected. Earnings for the top benefit class peak past age sixty, but ten to fifteen years earlier for the first and fifth classes. Of course, there is no reason that the underlying structure of KSW's model should not closely resemble these results.

The more pressing issue is that mean age-earnings profiles may obscure important underlying labor force patterns, and - interacting with a highly 
Table 8C.1 Age-65 Social Security Benefit Distribution (1999 dollars)

\begin{tabular}{|c|c|c|}
\hline Benefit Class & $\begin{array}{l}\text { Mean Actual Benefit in } \$ \\
\text { (Standard Deviation) }\end{array}$ & $\begin{array}{l}\text { Benefit Based on Mean } \\
\text { Earnings Trajectory (in \$) }\end{array}$ \\
\hline 1 st and 2 nd percentiles & $\begin{array}{l}1,234 \\
(334)\end{array}$ & 2,227 \\
\hline 3rd-10th percentiles & $\begin{array}{l}2,767 \\
(591)\end{array}$ & 2,423 \\
\hline 2rd decile & $\begin{array}{l}4,446 \\
(335)\end{array}$ & 3,427 \\
\hline 3th decile & $\begin{array}{l}5,330 \\
(200)\end{array}$ & 4,038 \\
\hline 4th decile & $\begin{array}{l}6,135 \\
(290)\end{array}$ & 5,489 \\
\hline 5th decile & $\begin{array}{l}7,276 \\
(358)\end{array}$ & 6,426 \\
\hline 6th decile & $\begin{array}{l}8,645 \\
(423)\end{array}$ & 7,994 \\
\hline 7th decile & $\begin{array}{c}10,038 \\
(382)\end{array}$ & 9,460 \\
\hline 8th decile & $\begin{array}{l}11,245 \\
(294)\end{array}$ & 11,784 \\
\hline 9th decile & $\begin{array}{c}12,417 \\
(493)\end{array}$ & 12,752 \\
\hline 91st-98th percentiles & $\begin{array}{c}14,465 \\
(629)\end{array}$ & 14,167 \\
\hline Top 2 percentiles & $\begin{array}{l}16,766 \\
(1,303)\end{array}$ & 14,846 \\
\hline
\end{tabular}

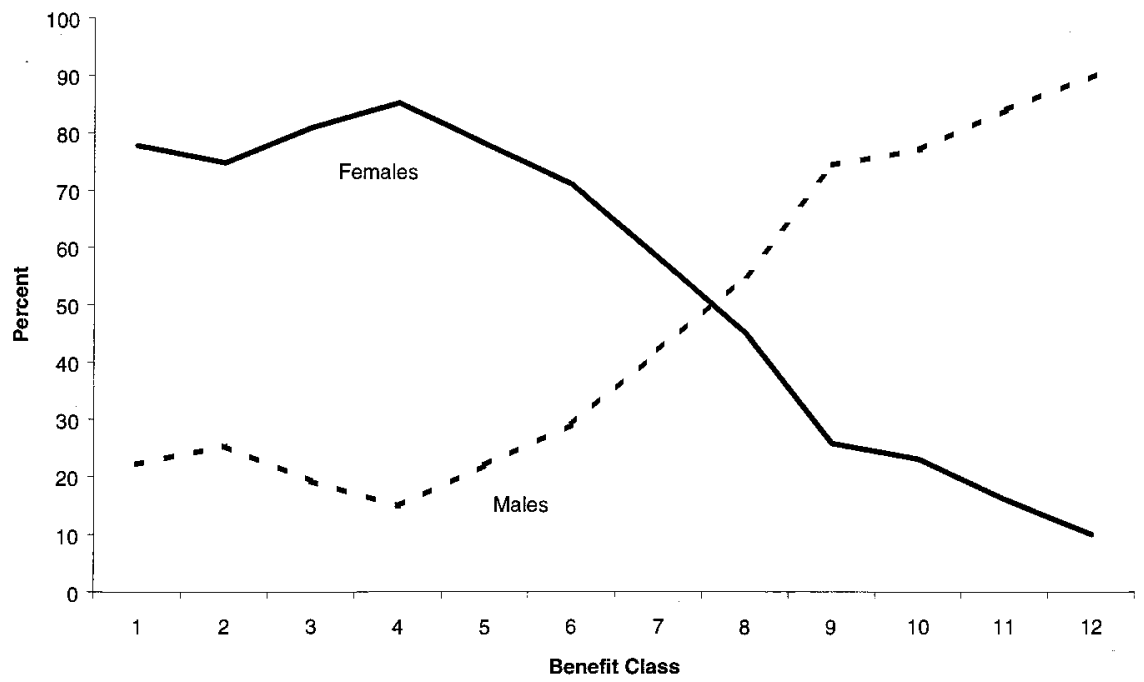

Fig. 8C.1 Male-female percentage distribution by age- 65 benefits 


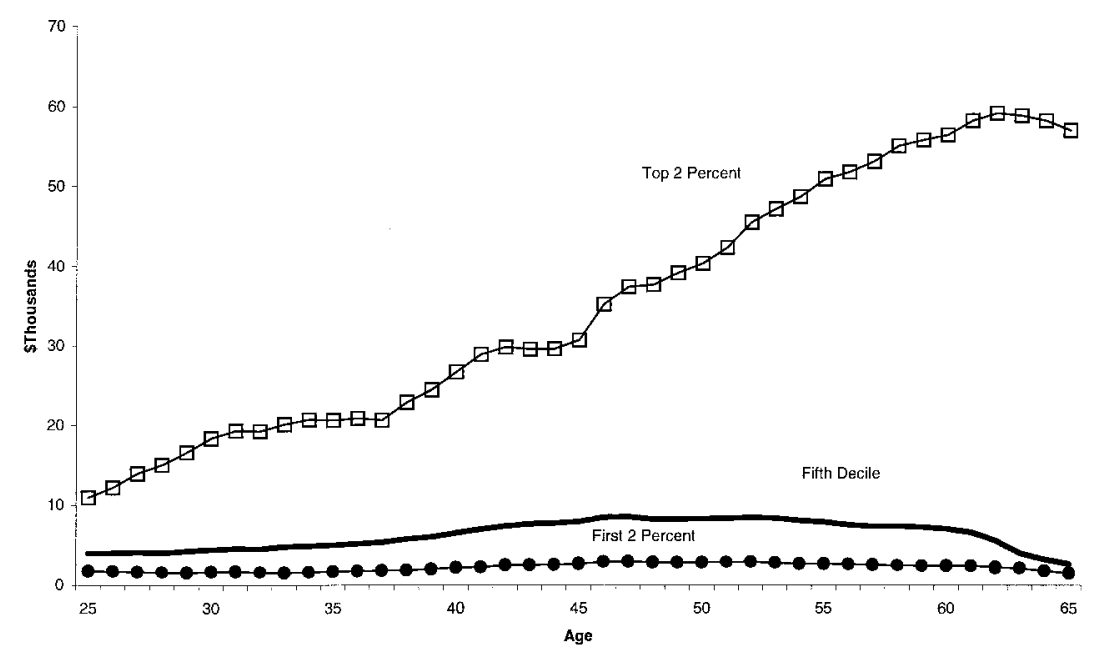

Fig. 8C.2 Real age-earnings profiles by benefit class

nonlinear benefit system - may generate misleading results. As we noted above, low-income individuals generally exhibit more intermittent labor force participation than higher-income individuals. This can be seen in figure 8C.3, which shows the differential incidence of years with zero earnings across the benefit classes, limiting the computation to the highest thirty-eight years of earnings. The percentage is very high for the lowest benefit classes but relatively small for the highest classes. Separate results for men and women (not shown) suggest that women have a higher incidence than men of years with no earnings, especially in the upper benefit classes.

Of course, the real issue of interest is whether the considerations we have raised suggest that some distributional analysis might be materially distorted. As a case study for this question, we have examined the distributional impact of increasing the number of years' worth of earnings included in the benefit formula from thirty-five to thirty-eight. (This change to the system has been a feature of many congressional and think-tank proposals for Social Security reform.) While this oft-proposed change in the benefit formula provides a convenient vehicle for illustrating our point, it is probably not the most consequential example. For example, the same types of effects would emerge in proposals to create individual accounts if the contribution into the account is zero unless annual earnings exceed some nonzero threshold.

The effect on worker benefits of such a change depends on whether it causes more low earnings to be added to the AIME and on the level of AIME. Workers with steady earnings in all years would be unaffected. 
Workers with low or zero earnings for the thirty-sixth through thirtyeighth years, on the other hand, would be affected most. Due to the progressive structure of the benefit formula, changes in the AIME result in larger changes for beneficiaries with low earnings and conversely for high earners.

We evaluated the effects of such a proposal on over 14,000 retired workers born in 1928 by first computing age-sixty-five retirement benefits under current law and then recomputing those benefits with the computation period increased by three years. Our results for males and females are summarized in figure 8C.4. Benefit reductions are uniformly higher for females than for males and larger for low- than for high-beneficiary classes.

\section{Conclusion}

We believe that the results described above illustrate a generic shortcoming of simulation models based on a very limited representation of heterogeneity in the population. To be clear, we believe that KSW have taken a useful step in introducing heterogeneity into their model. An interesting question - the answer to which we do not know - is whether at the current stage they have achieved only an uncomfortable middle ground, having introduced enough heterogeneity to invite contemplation of specific realistic reforms, but not enough to be able to deliver accurate answers.

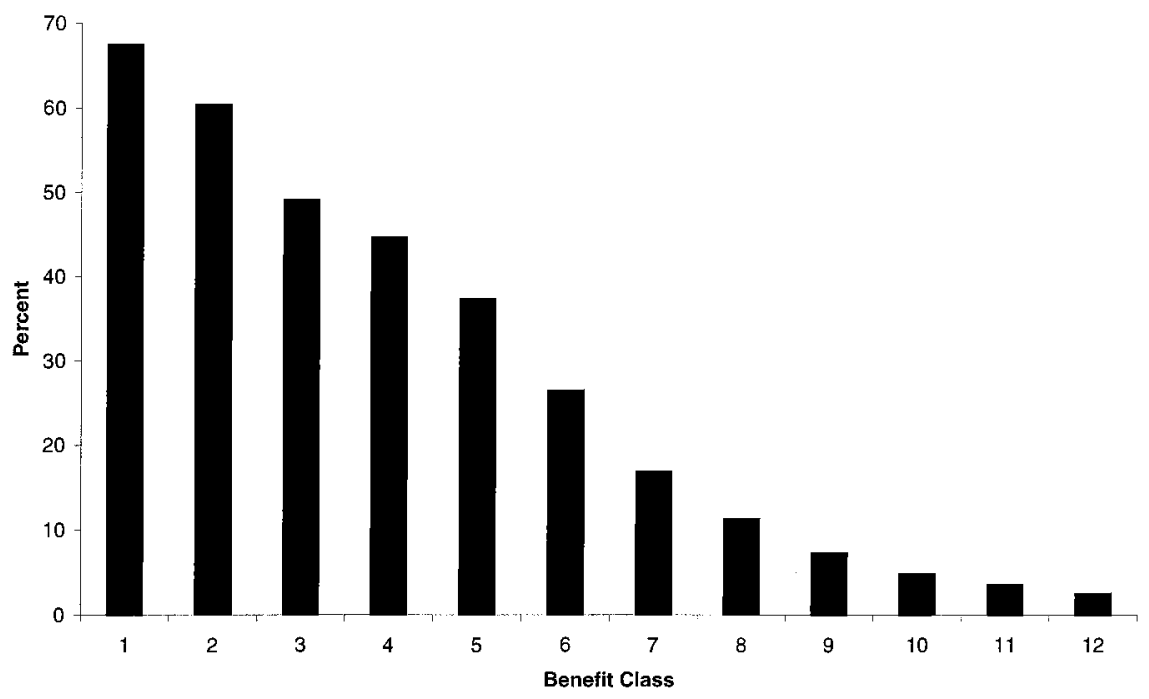

Fig. 8C.3 Percent of high 38 with zero earnings by benefit class 


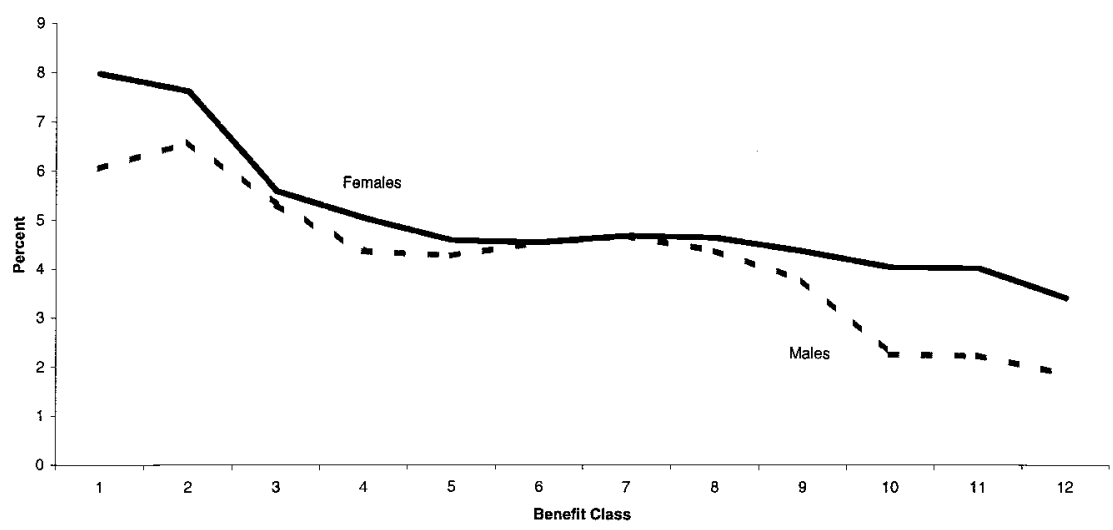

Fig. 8C.4 Percentage reduction in benefits from increasing the computation period by 3 years

\section{Reference}

Geanakoplos, John, Olivia Mitchell, and Stephen P. Zeldes. 1998. Would a privatized social security system really pay a higher rate of return? In Framing the social security debate: Values, politics, and economics, ed. R. Douglas Arnold, Michael J. Graetz, and Alicia H. Munnell, 137-56. Washington, D.C.: National Academy of Social Insurance.

\section{Discussion Summary}

Martin Feldstein noted that it was important that, after fifty years, the interest rate is only about one-tenth lower than it would otherwise be. Even in the very long run, the simulation shows an interest rate that is 8.5 percent instead of 9 percent. The general equilibrium effects on wages and real incomes are larger. However, long-run simulations of Social Security reform that ignore general equilibrium effects on interest rates are not assuming interest rates that are substantially different from what good general equilibrium analyses would imply.

Gary Burtless was concerned with the implementation of the minimum pension in the simulation. The simulation provides full minimum pensions for everyone without examining work histories. This is not consistent with the procedures followed by systems with minimum pensions. To be eligible for a full minimum pension, most systems require that an individual earn a minimum amount for thirty or thirty-five years. If a person only works twenty years, then he would not be entitled to a full minimum pension.

Andrew A. Samwick indicated that simplifications in general equilibrium 
models might lead to poor calibrations of the remaining parameters. For example, if the model is not designed to have precautionary saving, then the simulated consumers derived from the model's calibration will be more patient than the real consumers used to calibrate the model. Consequently, the evolution of the capital stock may be incorrect. 
